\title{
Climatic and tectonic controls on carbonate deposition in syn-rift siliciclastic fluvial systems: A case of microbialites and associated facies in the Late Jurassic
}

\author{
CONCHA ARENAS*, LAURA PIÑUELA $\dagger$ and JOSÉ CARLOS GARCÍA-RAMOS $\dagger$ \\ ${ }^{*}$ Dpto. de Ciencias de la Tierra, Universidad de Zaragoza, C/Pedro Cerbuna 12, 50009 Zaragoza, \\ Spain (E-mail: carenas@unizar.es) \\ $\dagger$ Museo del Jurásico de Asturias (MUJA), 33328 Colunga, Spain
}

Associate Editor - Daniel Ariztegui

\begin{abstract}
This work provides new insights to assess the factors controlling carbonate deposition in the siliciclastic fluvial systems of rift basins. Sedimentological and stable-isotope data of microbialites and associated carbonate facies, along with regional geological information, are shown to reveal the influence of climate and tectonics on the occurrence and attributes of carbonate deposits in these settings. The Vega Formation - a 150 m thick Lower Kimmeridgian siliciclastic fluvial sequence in Asturias Province (northern Spain) - constitutes a candidate for this approach. This unit includes varied facies (stromatolites; rudstones, packstones and wackestones containing oncoids, intraclasts, charophytes and shell bioclasts; marlstones and polygenic calcareous conglomerates) that formed in a low-gradient fluvial-lacustrine system consisting of shallow, low-sinuosity oncoid-bearing channels and pools within marshy areas, with sporadic coarse alluvial deposition. The sedimentological attributes indicate common erosion by channel overflow and rapid lateral changes of subenvironments caused by water-discharge variations. The carbonate fluvial-lacustrine system developed near uplifted marine Jurassic rocks. The occurrence of the system was conditioned by normal faults (active during the deposition of the unit) that favoured: (i) springs of $\mathrm{HCO}_{3}$-Ca-rich water from a Rhaetian-Sinemurian carbonate rock aquifer; and (ii) carbonate deposition in areas partially isolated from the adjacent siliciclastic fluvial system. The microbialite $\delta^{13} \mathrm{C}$ and $\delta^{18} \mathrm{O}$ values support deposition in a hydrologically open system, fed by ambient-temperature meteoric water, with riparian vegetation. Three types of lamination in the stromatolites and oncoids reflect distinct morphological types of cyanobacterial communities. The textural pattern of lamination parallels $\delta^{13} \mathrm{C}$ and $\delta^{18} \mathrm{O}$ changes, suggesting short-term cycles of precipitation and temperature. A moderately to strongly contrasted seasonal and/or pluriannual precipitation regime is inferred from the cyclic $\delta^{13} \mathrm{C}$ pattern of the lamination and from the discontinuous and asymmetrical growth of oncoids. Thus, the isotopic and sedimentological attributes of the carbonate deposits were linked to short-term climate changes associated with semi-arid conditions, consistent with the studied climatic zone.
\end{abstract}

Keywords Allocyclic factors, carbonates, fluvial-lacustrine facies model, microbialites, rift basin. 


\section{INTRODUCTION}

Laminated microbialites (i.e. stromatolites and oncolites) are common structures of fluvial and lacustrine environments in different types of basins throughout the geological record. Many ancient oncoidal and associated carbonate deposits are reported to occur mainly in fluvial and fluvial-lacustrine systems (Leinfelder \& Hartkopf-Fröder, 1990; Zamarreño et al., 1997; Hernández Gómez, 2000; Meléndez \& GómezFernández, 2000; Arenas et al., 2007; Astibia et al., 2012). During the Late Jurassic-Early Cretaceous these deposits were particularly abundant in relation to syn-rift fluvial and lacustrine systems (Leinfelder, 1985; Perry, 1994; Hernández Gómez, 2000; Meléndez \& Gómez-Fernández, 2000; Shapiro et al., 2009; Bosence, 2012); their occurrence and evolution have been explained in terms of both tectonic and climatic factors. Tectonics primarily control the origin and evolution of such continental basins, the extent and lithology of catchment areas and the preservation potential of deposits through subsidence (Miall, 1996). Most fluvial and fluviallacustrine carbonate systems are principally linked to water supplies from carbonate-rock catchments and aquifers, which are directly related to climate and bedrock structure (Ordóñez \& García del Cura, 1983; Evans, 1999; Dunagan \& Turner, 2004; Arenas-Abad et al., 2010).

Microbial lamination records a complex interaction of physical, chemical and biological parameters (Monty, 1976; Golubic, 1991; MerzPreiß \& Riding, 1999; Riding, 2000; Noffke \& Awramik, 2013) that greatly depend on climate and hydrology. The analysis of lamination in ancient microbialites has been the focus of many sedimentological works (Zamarreño et al., 1997; Seong-Joo et al., 2000; Suárez-González et al., 2014). However, the interpretation of the environmental and temporal significance of lamination from thickness and textural features is not always straightforward and unequivocal explanations are uncommon (Seong-Joo et al., 2000; Storrie-Lombardi \& Awramik, 2006; Petryshyn et al., 2012). The stable-isotope composition $\left(\delta^{13} \mathrm{C}\right.$ and $\left.\delta^{18} \mathrm{O}\right)$ reveals that lamination in microbialites can record short-term climatic and hydrological changes on different time scales (i.e. seasonal, interannual and decadal); therefore, laminated microbialites are considered high-resolution records of palaeoenvironmental conditions (Chafetz et al., 1991; Woo et al.,
2004; Andrews \& Brasier, 2005; Osácar et al., 2013).

The Late Jurassic record of Asturias (northern Spain, Fig. 1) mostly consists of a fluvial siliciclastic unit overlain by shelf lagoonal and deltaic sandstone, limestone and marl deposits, all of which formed in the extensional tectonic regime that affected the region from the beginning of the Late Jurassic to the Early Cretaceous (GarcíaRamos et al., 2011). The middle and distal fluvial deposits (mudstones and sandstones, Vega Formation) of the siliciclastic unit (Kimmeridgian) contain several limestone beds consisting of oncoids, intraclasts and bioclasts, along with calcareous conglomerate beds, that are interbedded at different stratigraphic positions (GarcíaRamos et al., 2010a,b). These carbonate deposits are the main focus of this work. Their distinct facies, their occurrence within a siliciclastic sequence and their close association with normal faults in the underlying marine Jurassic sequence provide an excellent scenario for discussion of the combined influence of tectonics and climate on the fluvial environment. In addition, well-preserved laminated structures in the oncoids provide an opportunity to examine the effects of environmental factors on microbial deposits through textural and stable-isotope analyses.

Based on the sedimentological and stable-isotope analyses of the carbonate deposits in the Vega Formation, complemented with regional stratigraphic data, the purpose of this work was: (i) to characterize the different carbonate facies and depositional environments and propose a sedimentary facies model that explains their distribution and evolution through space and time; (ii) to infer the climatic conditions and their imprint in the microbial laminated deposits; and (iii) to discern the influence of climate and tectonics on the occurrence and evolution of the carbonate deposits. The results provide new insights that may help to interpret other examples in which carbonate deposits develop in association with siliciclastic fluvial systems in rift basins.

\section{GEOLOGICAL SETTING - SEDIMENTOLOGY AND PALAEOGEOGRAPHY OF THE JURASSIC IN THE STUDIED AREA}

The most spectacular and best-preserved Jurassic outcrops in Asturias (northern Spain) extend almost continuously along a narrow section of 
A
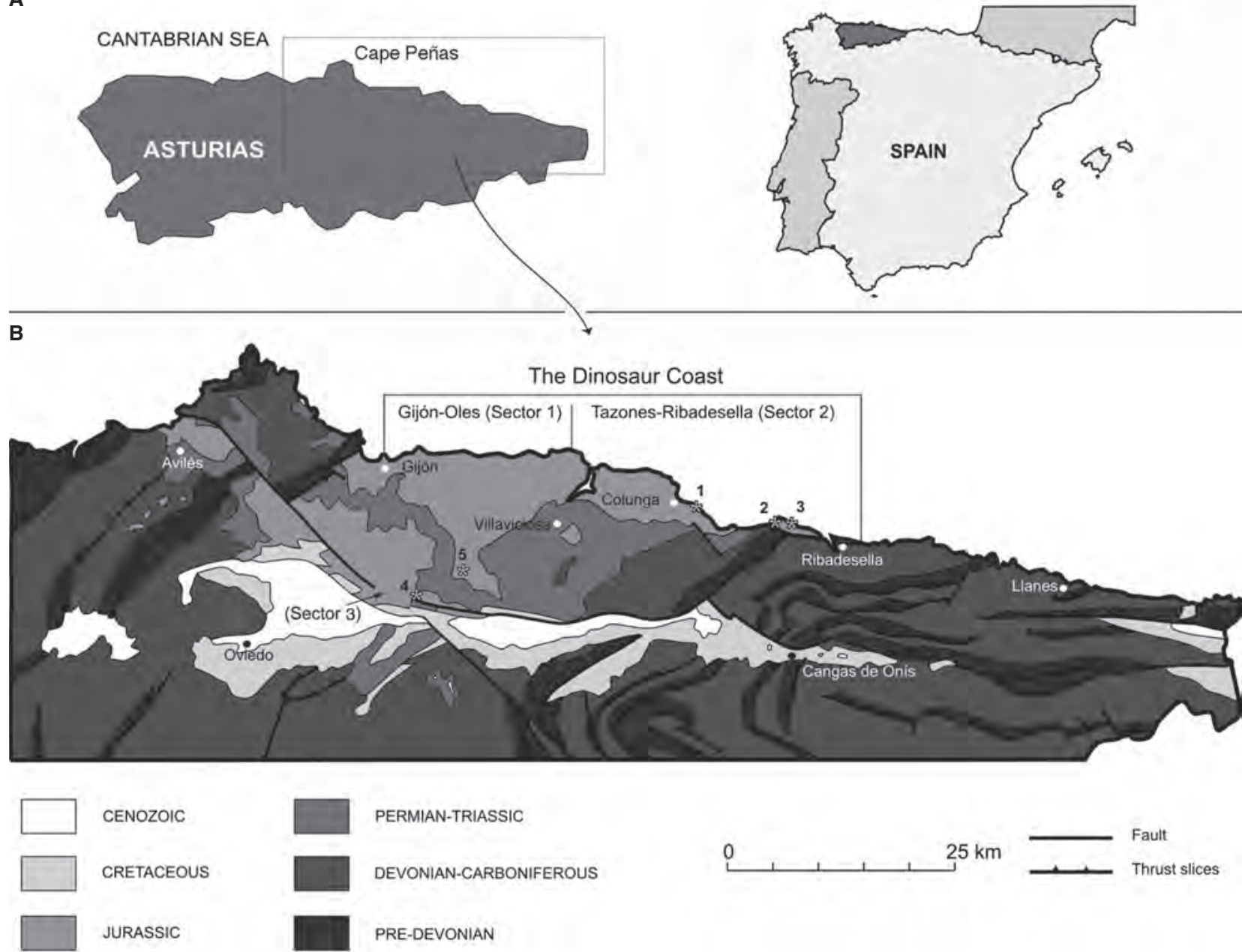

Fig. 1. Location (A) and geological map of the area (B), with the main studied sections: 1 - La Griega-Lastres; 2 - Vega; 3 - Abeu; 4 - La Fumarea; 5 - Fuente del Gato.

coast (ca $60 \mathrm{~km}$ long) between the Cabo Torres, in Gijón, and Arra beach, in Ribadesella (GarcíaRamos et al., 2011; Fig. 1). The Jurassic outcrops are part of the so-called Gijón-Villaviciosa Basin (Ramírez del Pozo, 1969), whose western end is bounded by the Veriña fault, located $2 \mathrm{~km}$ west of Gijón (Lepvrier \& Martínez García, 1990). The basin extends eastward to the Ribadesella fault, coinciding with Arra beach (Alonso et al., 2009). The Jurassic to Cenozoic rocks in eastern Asturias (Fig. 1B) overlie diverse Variscan units (Precambrian to Carboniferous of the Cantabrian Zone) and Permian-Triassic units. Further west and south, outside of Fig. 1B, mostly Variscan pre-Devonian rocks crop out (Western AsturianLeonese Zone) (Aramburu \& Bastida, 1995).

The Jurassic record of Asturias (Fig. 2A) begins with a succession of limestones, dolostones and marls (Gijón Formation) that originated on a low and irregular coast, rich in carbonate muds and evaporites (coastal sabkha). This succession also includes some stratiform calcareous breccias of metre-scale thicknesses. Their origin is related to dissolution of gypsum layers intercalated among highly fractured limestones (collapse breccias; Valenzuela et al., 1986; García-Ramos et al., 2006).

During the Late Sinemurian, a gradual relative rise in the sea-level caused a great part of the region to be submerged, at times to depths greater than $100 \mathrm{~m}$. The Rodiles Formation represents the resulting marine deposits. This formation has two distinct parts (Fig. 2A): the lower part is made up of nodular limestones with several thin marly layers, representing the proximal portion of a carbonate ramp; the overlying part features layers of limestones and marls, with tabular geometry and rhythmic 


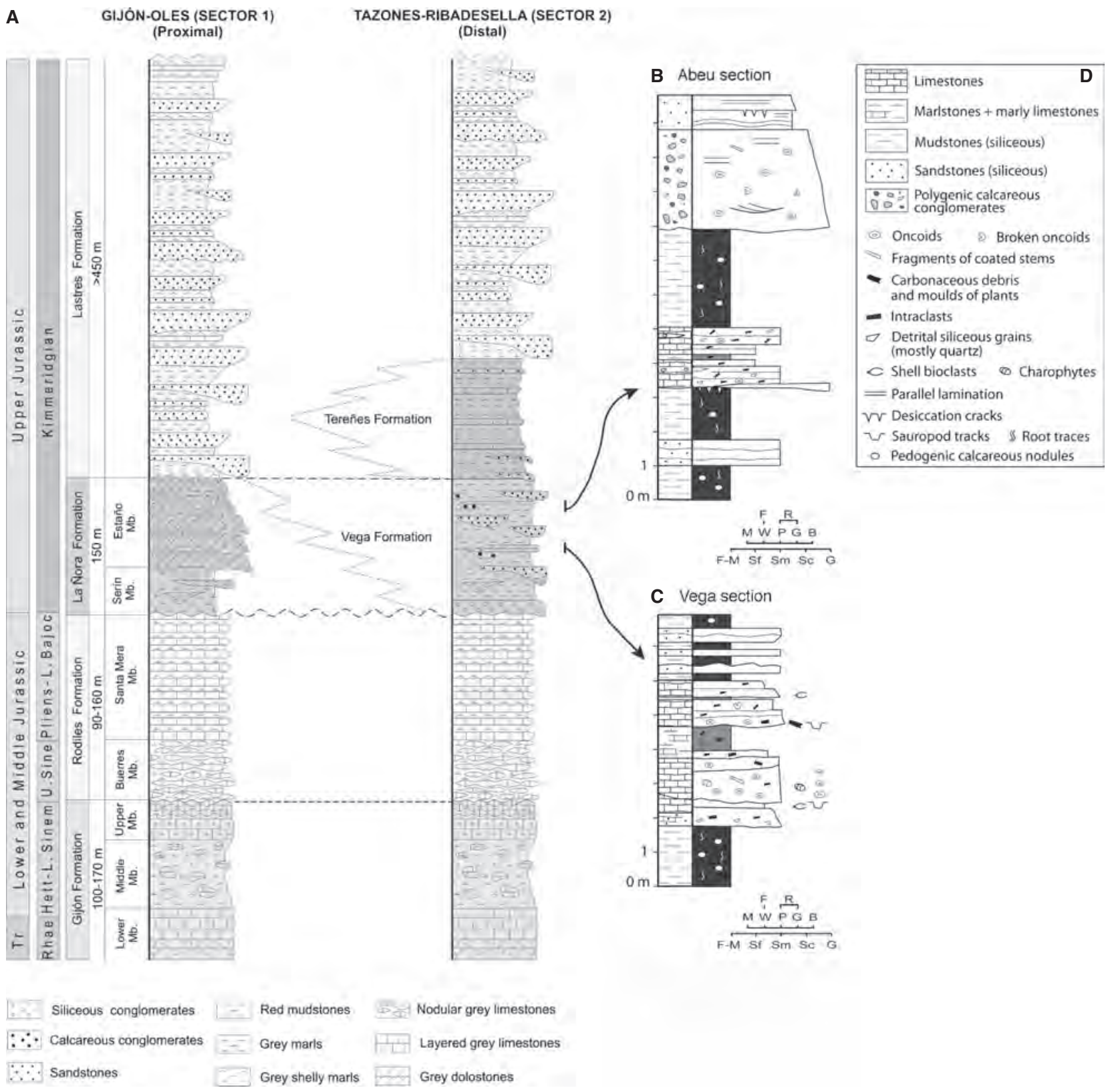

Fig. 2. (A) General stratigraphic sections of the Jurassic in Asturias (present coastal sectors). Modified from García-Ramos et al. (2006, 2011). (B) and (C) Detailed stratigraphic sections with carbonate intervals (see Fig. 1B for location). (D) Legend for (B) and (C) - Abeu and Vega sections. Texture and lithology of stratigraphic sections (B) and (C): $\mathrm{M}$ - mudstone; $\mathrm{W}$ - wackestone; $\mathrm{P}$ - packstone; $\mathrm{G}$ - grainstone; $\mathrm{B}$ - boundstone; $\mathrm{F}$ - floatstone; $\mathrm{R}$ - rudstone. M-F - marls and fines; S - sand; G - gravel.

character, representing the middle and external portions of the ramp (Valenzuela et al., 1986; Bádenas et al., 2012).

At the beginning of the Late Jurassic, a drastic change in the landscape occurred due the activity of extensional faults, which eventually produced the uplift and emergence of part of the territory - including a great area of Asturias, which was submerged during the Early and
Middle Jurassic - giving rise to new coastlines and emerged lands that were soon colonized by dinosaurs and other coetaneous vertebrates. The uppermost carbonate marine succession was erosively truncated by Late Jurassic siliciclastic fluvial sediments. The youngest marine rocks underlying the fluvial succession are Early Bajocian in age (Suárez Vega, 1974). This tectonic activity, controlled by extensional faults, 
represented the first stages of rifting that ended in the Early Cretaceous. The activity generated an uplifted area in the south-western part of the region, within the Western Asturian-Leonese Zone, whose erosion provided the first contributions of siliciclastic continental sediments to the basin (García-Ramos, 1997). Then, karstification of the emerged marine carbonate successions of the uppermost Triassic and Lower and Middle Jurassic occurred, leading to the formation of decalcification clays, collapse breccias and palaeovalleys excavated in the underlying calcareous rocks (García-Ramos et al., 2006).

In the western part of the basin (sector 1 in Figs $1 \mathrm{~B}$ and $2 \mathrm{~A}$ ), coarse clastic sediments of alluvial origin accumulated, initially filling the palaeovalleys and karstic cavities. The succession is composed mainly of siliceous conglomerates, with small intercalations of sandstones, and red mudstones with calcareous palaeosols, arranged vertically into metre-scale finingupward cycles. These rocks constitute the La Nora Formation. To the north-east (sector 2 in Figs $1 \mathrm{~B}$ and $2 \mathrm{~A}$ ), the La Nora Formation grades laterally to alternating white, grey and reddish sandstones and red mudstones with several conglomeratic beds (Vega Formation), all of which are siliceous in nature, likewise arranged in minor fining-upward cycles within a major cycle of the same character (García-Ramos et al., 2010a). These rocks represent fluvial deposits formed by ephemeral and highly sinuous streams separated by extensive floodplains on which calcareous palaeosols (calcretes) developed (García-Ramos et al., 2010a; Gutierrez \& Sheldon, 2012). Deposits consisting of intraclastic and oncoidal limestones, as well as sparse polygenic calcareous conglomerates, are interbedded within the siliciclastic fluvial succession. These limestones were interpreted to represent deposition in ponds partly fed by a number of freshwater carbonate-rich springs coming from faulted zones of the uppermost Triassic-Lower Jurassic carbonate rocks (García-Ramos et al., 2010b). These limestone strata and the associated polygenic conglomeratic beds of the Vega Formation are the main focus of this work (Fig. 2).

Another relative rise in the sea-level drove the coastline into the interior of present Asturias. A restricted shallow sea developed (a shelf lagoon), separated from the ocean by a threshold or barrier of tectonic origin that impeded the entry of marine fauna. A thick sequence of calcareous dark muds, rich in organic matter and brackish invertebrate fauna (bivalves, gastropods and ostracods), accumulated (Tereñes Formation; Fürsich et al., 2012). This area also served as a refuge for crocodiles, turtles and fishes. Interbedded mudstones, sandstones, marls and minor limestones that formed in fluvial-dominated deltaic systems constitute the Lastres Formation (García-Ramos et al., 2006, 2011), completing the Jurassic succession in this region.

\section{The Vega Formation: studied sections}

The Vega Formation crops out as incomplete sections in different fault-affected areas of Asturias, rendering it difficult to accurately measure the total thickness of the unit. The estimated thickness is $c a 150 \mathrm{~m}$. The unit contains several limestone and polygenic calcareous conglomerate strata with distinct facies that are interbedded at different stratigraphic positions throughout the siliciclastic sequence (Figs 2 and 3).

The studied sections that contain limestone intervals are distributed in the north-east (sector 2; Fig. 1B) and in the south-west (sector 3; Fig. 1B). The lithostratigraphic attribution of limestones in sector 3 has not yet been formally established, but their stratigraphic position and abundance of oncoidal facies support their occurrence in a time-equivalent unit to the Vega Formation. For the purposes of this study, the oncoidal limestones in sector 3 are considered to belong to the Vega Formation. In sector 3, where the formation is thinner and finer relative to sector 2, the total thickness of limestone intervals is greater than along the coast (sector 2), where thicker siliciclastic deposits occur. In the south-western outcrops (sector 3), although the exposures are poor, the thickness of single limestone intervals is estimated to be ca $3 \mathrm{~m}$. These limestones, formerly termed pisolitic limestones (Ramírez del Pozo, 1969), chiefly correspond to oncoidal rudstones. In the north-eastern outcrops (sector 2), single limestone intervals are up to $c a 4 \mathrm{~m}$ thick, and commonly have sharp contacts with the underlying and overlying siliceous sandstone and mudstone deposits. These limestones consist of decimetre-thick to metrethick tabular and gently lenticular strata of intraclast-oncoid rudstones and packstones, bioclast (bivalve, ostracod and charophyte) and intraclast wackestones, and rare stromatolites (Fig. 2B and C). Conglomeratic beds (mostly of polygenic calcareous clasts) occur underlying and within the limestone succession (for example, in section 1). Locally, the conglomerates 

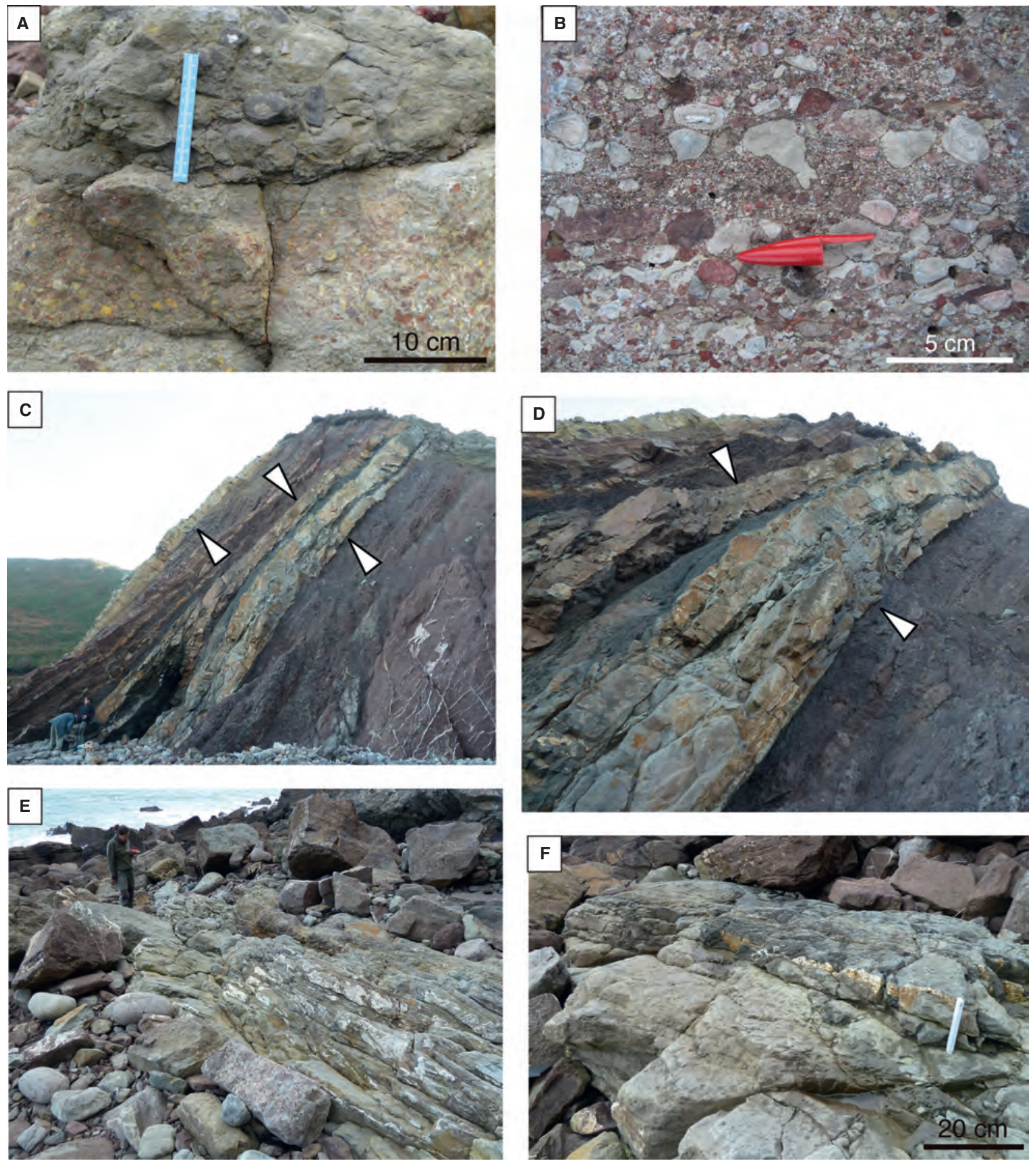

Fig. 3. Field views of limestone and marlstone beds (arrows) and associated conglomerates interbedded within the siliciclastic deposits of the Vega Formation. (A) Polygenic calcareous conglomerates overlain by an oncoid rudstone (La Griega section). (B) Detail of conglomerate texture: these are mostly composed of calcareous clasts (light grey-coloured and dark reddish-coloured marine Jurassic rocks and limestones of the Vega Formation) and less abundant siliciclastic clasts (quartz grains and reddish mudstones). (C) Vega section; note the gypsum veins and pedogenic features (calcite nodules and bioturbation) in the thick mudstone beds at the base. Persons for scale are $\mathrm{ca} 1.8 \mathrm{~m}$ tall. (D) Detail of (C) showing tabular, lenticular and gentle channel-shaped geometry of limestone and marlstone strata. The interval between the arrows is ca 2 m thick. (E) and (F) - Abeu section: (E) Gentle channel-shaped deposit consisting of oncoid-intraclast rudstones; person for scale is $\mathrm{ca} 1.8 \mathrm{~m}$ tall. (F) Rudstone containing mostly intraclasts; note the darker grey colour at the top (see Fig. 1B for location). 
can be up to $3 \mathrm{~m}$ thick (Fig. 2B). Occasionally, tabular beds, up to $10 \mathrm{~cm}$ thick, of siliceous sandstones and microconglomerates are found to be interbedded with the limestone strata (for example, in sections 1 and 4; Fig. 1B).

\section{METHODS}

Samples of different carbonate facies from the studied sections were collected for analysis of their textural features, mineralogy and stableisotope compositions. A total of 29 thin sections and 35 polished slabs were prepared for inspection by means of optical microscopy. Eight samples were examined by scanning electron microscopy using a JEOL JSM 6400 (JEOL Limited, Tokyo, Japan) of the Servicio de Microscopía Electrónica at the University of Zaragoza (Spain). Unfortunately, the results were poor in relation to microbial remain findings.

Samples were selected for mineralogy and for stable-isotope analyses after inspection with a petrographic microscope. The samples were obtained from the correlative polished slabs, selecting the parts of the rock with minimum presence of cements or recrystallization features (as determined in the thin sections). For the mineralogical analysis, samples were ground and sieved $(53 \mu \mathrm{m})$. For the stable-isotope analysis, powdered samples of rock were obtained through drilling (with a microdrill) in the selected areas, which were magnified with a stereo microscope. These samples corresponded to light and dark laminated intervals in the microbialites, as well as bulk oncoid coatings and the matrix between oncoids.

The mineralogical composition of 17 samples was determined by X-ray diffraction (XRD). The analyses were carried out at the X-ray Diffraction and Fluorescence Analysis Service of the University of Zaragoza (Spain) using a D-Max Rigaku diffractometer (Rigaku Corporation, Tokyo, Japan) equipped with a graphite monochromator and CuKa radiation.

The stable-isotope ratios $\left(\delta^{13} \mathrm{C}\right.$ and $\left.\delta^{18} \mathrm{O}\right)$ of 46 calcite samples were determined at the Servicios Científico-Técnicos (CCIT-UB Serveis) of the University of Barcelona (Spain). The $\delta^{13} \mathrm{C}$ and $\delta^{18} \mathrm{O}$ values were measured in a mass spectrometer (MAT-252, Thermo Finnigan; Thermo Fisher Scientific, Waltham, MA, USA) via $\mathrm{CO}_{2}$ obtained in a Carbonate Kiel Device III (Thermo Finnigan) by the reaction of samples with $100 \% \mathrm{H}_{3} \mathrm{PO}_{4}$ at $70^{\circ} \mathrm{C}$ for $3 \mathrm{~min}$ (McCrea, 1950). The interna- tional standard NBS-19 $\left(\delta^{13} \mathrm{C}_{\mathrm{V}-\mathrm{PDB}}=+1.95 \%\right.$ and $\delta^{18} \mathrm{O}_{\mathrm{V} \text {-PDB }}=-2 \cdot 20 \%$ ) was used. The results are reported in $\delta \%$ notation relative to Vienna Pee Dee Belemnite (V-PDB). The overall reproducibility was better than $\pm 0 \cdot 04 \%$ for $\delta^{13} \mathrm{C}$ and $0 \cdot 12 \%$ for $\delta^{18} \mathrm{O}$. The results of the mineralogical and isotopic analyses are shown in Appendices 1 and 2.

\section{CARBONATE DEPOSITS OF THE VEGA FORMATION}

The carbonate deposits of the Vega Formation consist of several limestone beds and polygenic conglomeratic beds interbedded at different stratigraphic positions within the general fluvial sequence of siliceous mudstones, sandstones and conglomerates (Fig. 2). The limestone samples consist of calcite, minor quartz and less abundant phyllosilicates (muscovite and kaolinite), as determined by XRD and microscope analyses (Appendix 1). These siliceous detrital particles (determined through optical microscopy) commonly represent 1 to $10 \%$ of the sample, but in some cases as much as $35 \%$. Therefore, some samples correspond to quartz-rich limestones. Samples containing calcite and up to $76 \%$ of siliceous grains correspond to siliceous-calcareous sandstones and microconglomerates. Based on the textural characteristics, several carbonate facies are distinguished (Table 1). The most abundant limestone facies are the oncoid rudstones, followed by the oncoid-intraclast rudstones and packstones. These two facies are present in all studied sections (Table 1).

\section{Polygenic calcareous conglomerates (Co)}

The conglomerates, exceptionally up to $4 \mathrm{~m}$ thick, are arranged in decimetre-thick tabular and lenticular (channel-shaped) strata that generally occur as isolated bodies within the siliciclastic mudstones and also are associated with the limestone intervals (for example, in sections 1 and 3), commonly underlying them (Fig. 3A); they either fine-upward or lack grain-size variation. Commonly, these bodies are structureless, but in certain cases they exhibit trough crossstratification and horizontal stratification.

These are clast-supported rocks composed of carbonate clasts from different underlying Jurassic marine units and from limestones of the Vega Formation. Less abundant and smaller siliceous clasts (mainly of fine sandstones and siltstones/mudstones) are also present (Fig. 3B). 


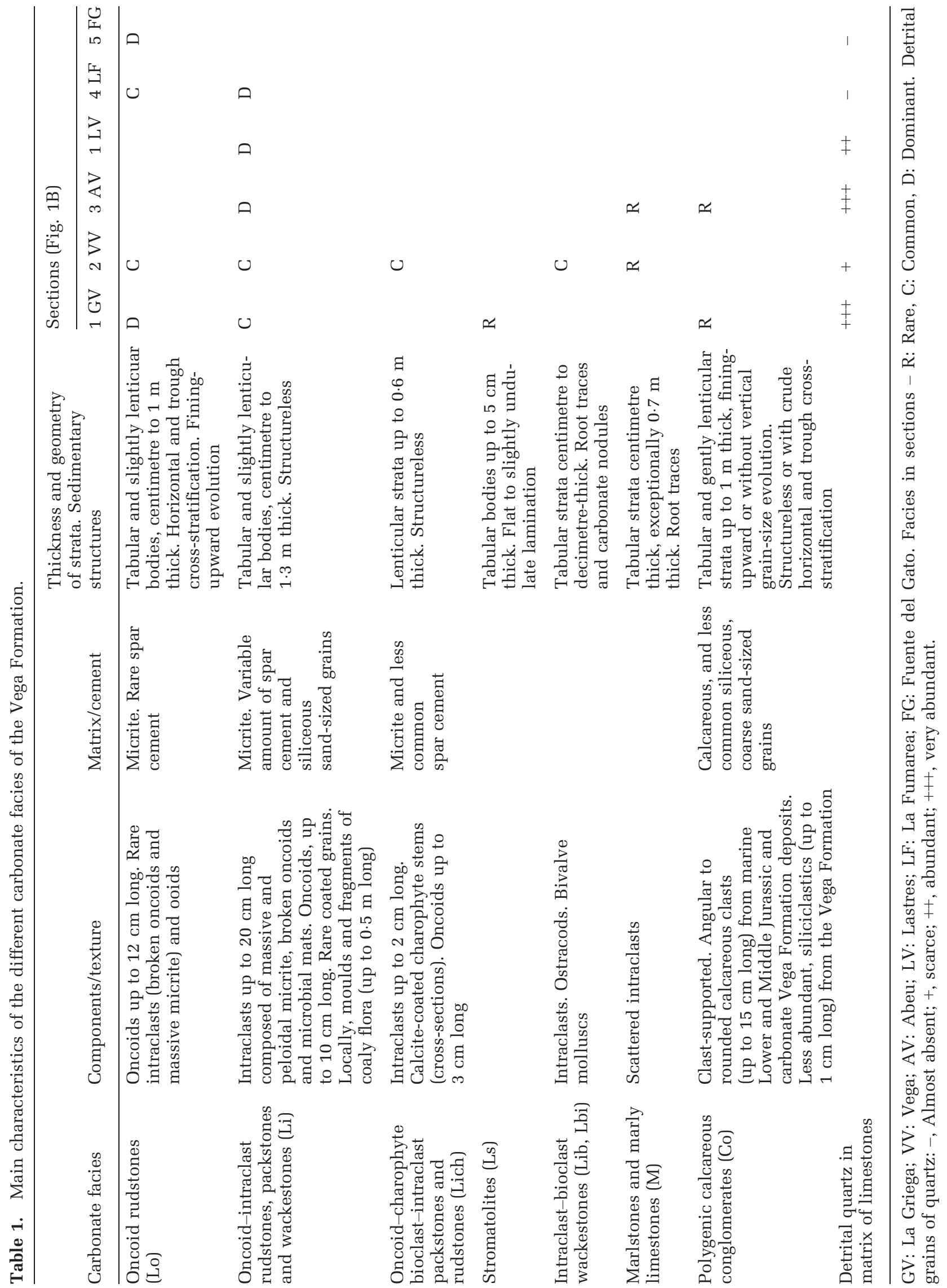


The varied colour of clasts led to them being described as 'poudingues fleuris' (Ciry, 1940; Rat, 1962; Hernández Gómez, 2000). Similar conglomerates have been described in the Campóo Group (Upper Jurassic-Lower Cretaceous) in northern Spain (Pujalte et al., 1996). In the study area, the clasts are poorly sorted; the carbonate clasts range from a few millimetres to $15 \mathrm{~cm}$ in diameter and are poorly to well-rounded. The siliceous clasts are up to $1 \mathrm{~cm}$ in diameter and range from angular to subrounded. The matrix consists of sand-sized carbonate detrital particles and very minor siliceous particles.

These deposits formed through deposition of coarse sediments by mostly sheet-like and gently channelized currents. The clast sizes and the association of the conglomerate deposits with siliciclastic mudstones suggest that this facies formed in middle to distal areas of alluvial fans. A similar interpretation was made for the microconglomerates containing microbialite intraclasts in the Upper Oligocene alluvial deposits of north-eastern Spain (Parcerisa et al., 2006). In general, these deposits are associated with highenergy to moderate-energy events in alluvial fans (Miall, 1996; López-Gómez \& Arche, 1997; Kumar et al., 2007). In the study area, the conglomerate composition indicates that the alluvial fans were sourced from the Jurassic marine limestones and, downstream, the ephemeral currents flowed over deposits of the concurrent carbonate and siliciclastic fluvial systems of the Vega Formation.

\section{Stromatolites (Ls)}

Stromatolites are rare and limited to a few planar layers up to $5 \mathrm{~cm}$ thick, interbedded within oncoidal limestone strata in the La Griega section (Fig. 4A). More commonly, fragments of stromatolitic deposits are found as intraclasts of highly variable size and shape in the oncoidal and intraclastic limestones at a number of sites (Fig. 4B and C). The lamination of stromatolites is flat to slightly wavy. Both the internal structure and the texture are similar to those of oncoids that are described in detail below.

The limited exposure of stromatolitic deposits precludes a precise interpretation. In other fluvial carbonate-rich contexts, stromatolites represent both low-energy conditions (for example, linked to final deposition in abandoned channels and pools; Leinfelder, 1985; Arenas et al., 2007) and high-energy conditions (for example, fluvial stretches with increased slope; Vázquez-Urbez et al., 2010, 2012). The lack of geometrical attributes and associated facies indicative of highslope depositional areas in the studied context suggests that stromatolites probably formed in calm to low-energy conditions after the waning of energy in fluvial channels or in shallow pools, some of which could have formed through the isolation of oncoidal channels. A similar interpretation was given to stromatolites of the Kimmeridgian in Portugal (Leinfelder, 1985), the Tertiary in the Ebro Basin (Zamarreño et al., 1997; Vázquez-Urbez et al., 2013) and the Quaternary of Lake Natron (Casanova, 1994). During high-energy episodes produced by increased water discharge, stromatolites and associated deposits (for example, oncoidal and bioclastic facies) would have been eroded, and their fragments redeposited in nearby fluvial areas, mostly in channels.

\section{Oncoid rudstones (Lo)}

Deposits composed of this facies are common in all sections and consist of tabular, undulate and lenticular strata, with channel-shaped bases in places, that are decimetres to $1 \mathrm{~m}$ thick (Figs 3A, 3C and 4D). The strata can be grouped into tabular or lenticular intervals up to $1.5 \mathrm{~m}$ thick, commonly associated with deposits of other carbonate facies within thicker tabular intervals (up to $4 \mathrm{~m}$ thick, in the Vega section; Fig. 2C). In some cases, the strata show coarse horizontal and trough cross-stratification (Fig. 4D and E). The general trend of the individual strata is usually fining-upward, based on the size and/or volume of allochems. In some cases, strata composed of this facies contain dark grey-coloured intraclasts and oncoids at the top. Oncoid-intraclast rudstones overlie this facies.

This facies is composed of oncoids and commonly includes a small percentage of broken oncoids, calcite-coated phytoclasts, stromatolite fragments, isolated microbial calcite bodies and/ or rare coated grains. Ooids may also be present in certain sites (for example, section 1), locally forming packstones and grainstones. Dark grey to light grey, massive micritic fragments also occur. In general, these components range from submillimetre to $28 \mathrm{~cm}$ long (Figs $4 \mathrm{C}$ to $\mathrm{E}$ and $5 \mathrm{~A}$ to $\mathrm{E}$ ). The matrix is composed of micrite and occasionally rounded micrite intraclast wackestone to packstone (Figs $5 \mathrm{~F}$ and 6A). Spar cement is not abundant. Detrital siliceous 

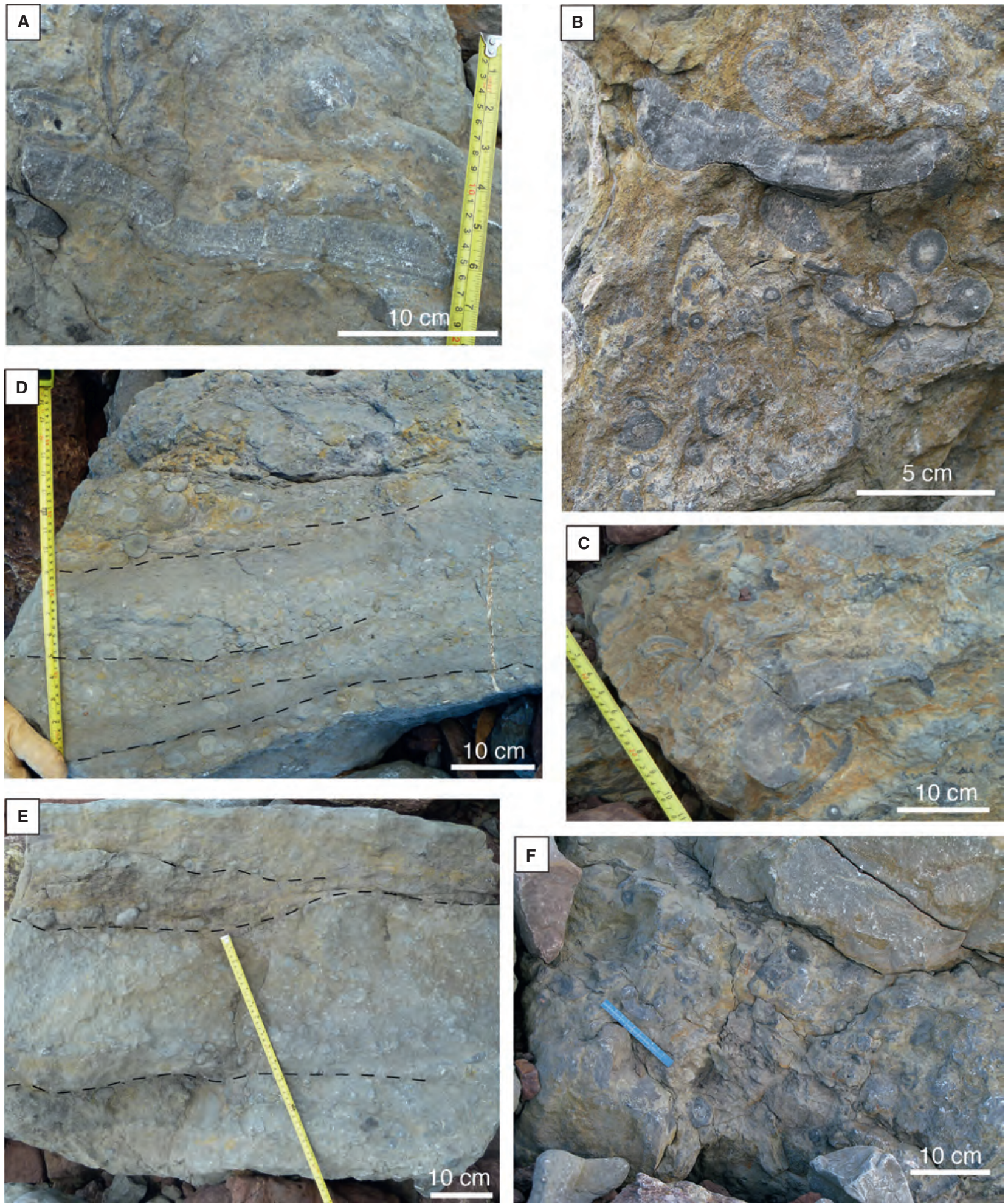

Fig. 4. Field views of stromatolites and oncoid rudstones of the Vega Formation. (A) Undulate layer of stromatolites among an oncoid rudstone. (B) Oncoids and an overturned stromatolite or oncoidal fragment. Note the round nuclei in certain oncoids. (C) Oncoid rudstone containing a convex-up stromatolite fragment. (D) Gentle channel-shaped surfaces and trough cross-stratification in an oncoid rudstone. Note the finingupward evolution of oncoids within the layers. (E) Irregular and gentle channel-shaped surfaces bounding the fining-upward layers in an oncoid rudstone. (F) Oncoid-intraclast rudstone passing upward into an intraclast packstone. 

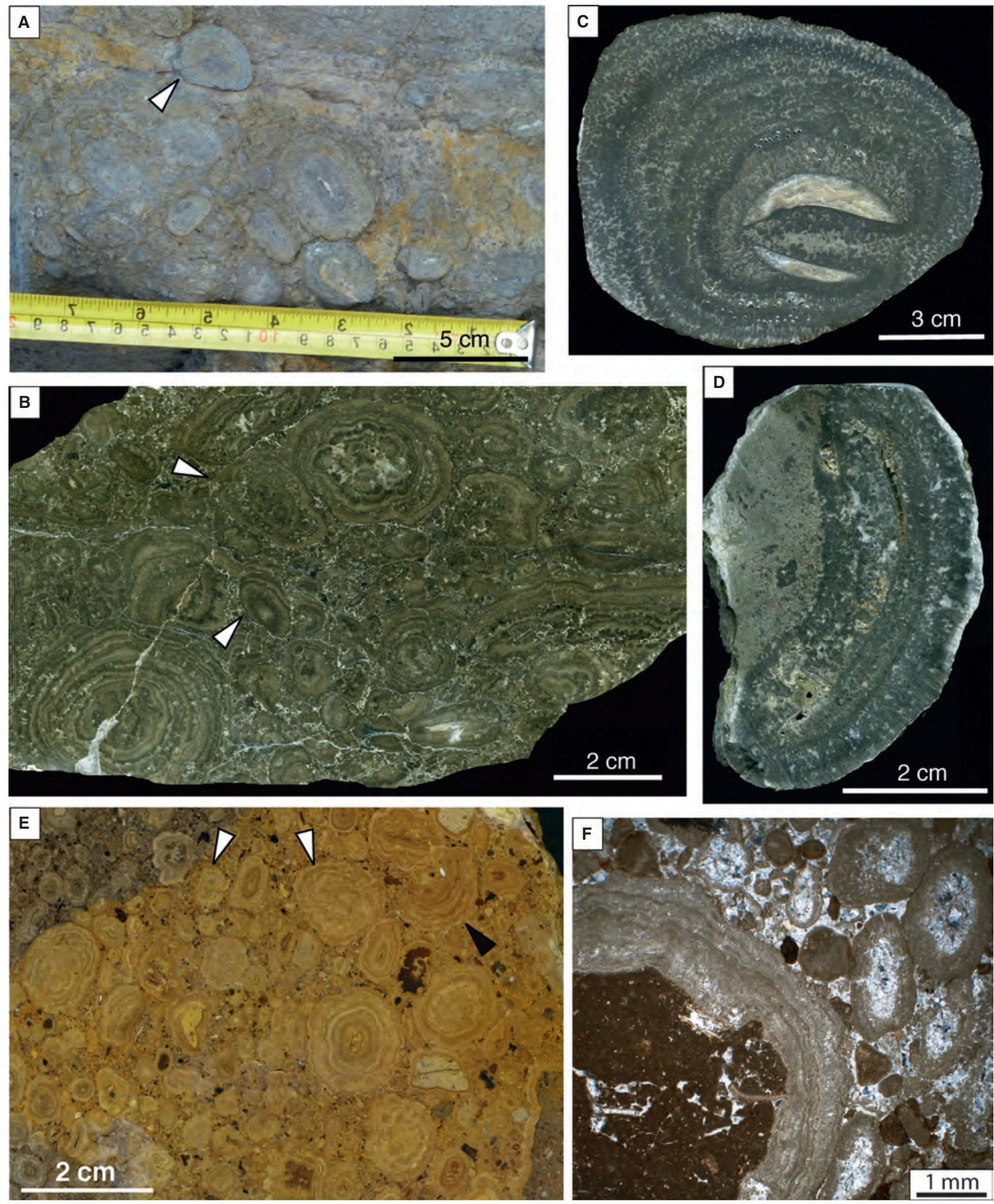

Fig. 5. Field views and hand samples of oncoids and oncoid rudstones. (A) and (B) Rudstones containing oncoids with elliptical and round sections. Asymmetrical and truncated oncoids are indicated by arrows. Note the stromatolite fragment in (B). (C) and (D) Asymmetrical oncoids developed on bivalves. (E) Rudstones containing symmetrical and asymmetrical (arrowed) oncoids developed on various nuclei including grey-coloured limestone and yellow to red-coloured mudstone extraclasts, as well as intraclasts. Note the small particles of these compositions among the oncoids. (F) Partial view of an asymmetrical oncoid developed on an intraclast consisting of bioclast-intraclast packstone. Surrounding mass: micrite intraclasts, ooids and smaller oncoids (with sparry nuclei) within spar cement. 

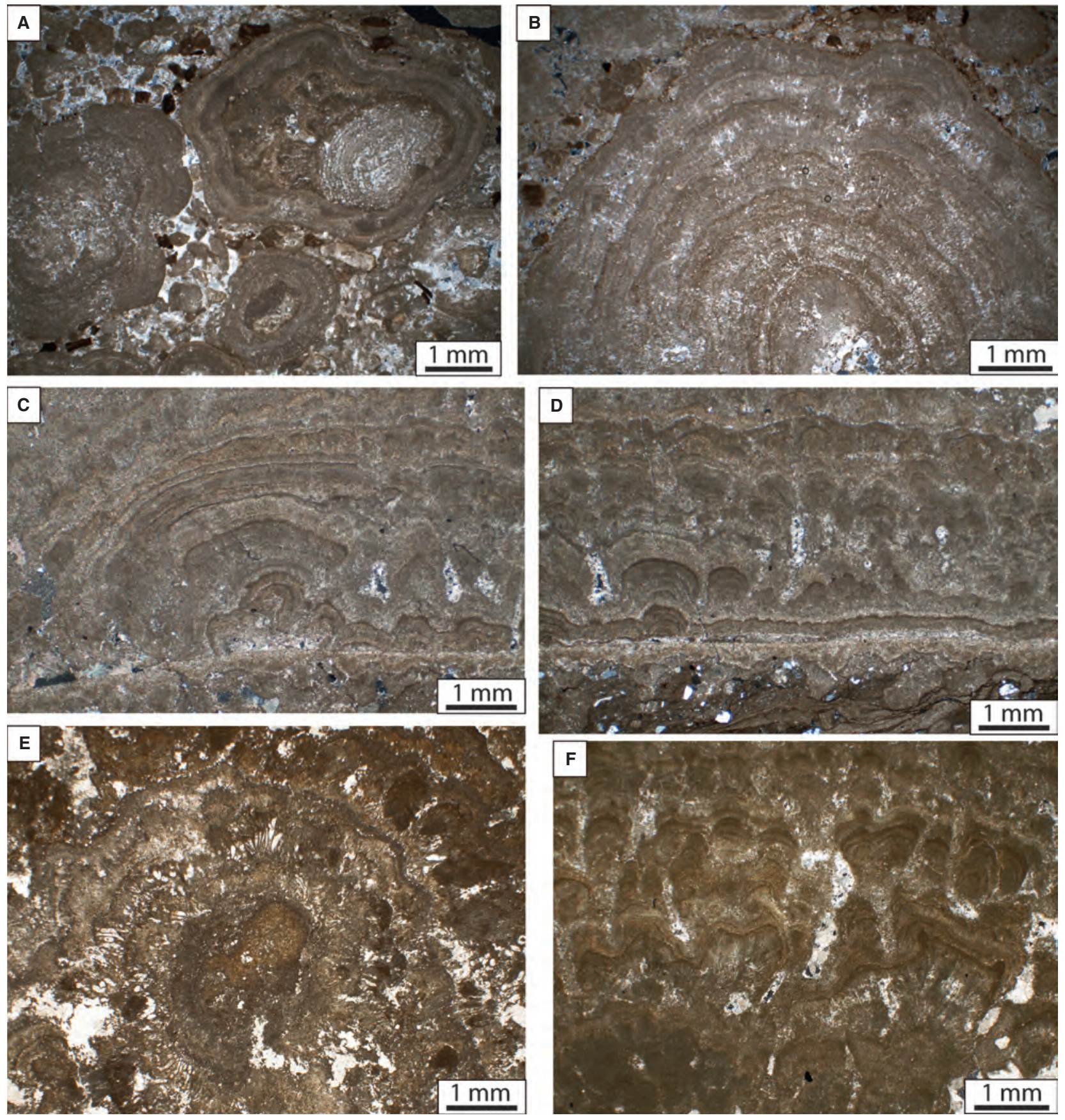

Fig. 6. Photomicrographs (optical microscope) of oncoids and types of lamination. (A) Oncoid rudstone. Note the asymmetrical growth on the laminated nucleus and erosion of the outer laminae. (B) Slightly wavy laminae in an oncoid (type 1 lamination). (C) and (D) Domed and columnar structures (type 3 lamination) at the base and chiefly flat laminae toward the top of (C). Note the lateral change from small domes to flat laminae at the base of (D). (E) Wavy and irregular laminae (type 2 lamination). (F) Columnar structure that characterizes type 3 lamination.

particles (mostly single quartz grains, up to $1 \mathrm{~mm}$ in diameter, and mudstone clasts, up to $5 \mathrm{~mm}$ in diameter) can be found scattered in the matrix (Figs 5E, 7C and 8D).

In general, the oncoidal deposits formed in wide and shallow channels of low sinuosity and in ponds, where oncoids developed in slow-flowing conditions, as recognized in modern rivers and lakes (Ordóñez et al., 1980; Hägele et al., 2006), and in many ancient fluvial and lacustrine systems (Leinfelder \& Hartkopf-Fröder, 1990; Zamarreño et al., 1997; Arenas et al., 2007; 

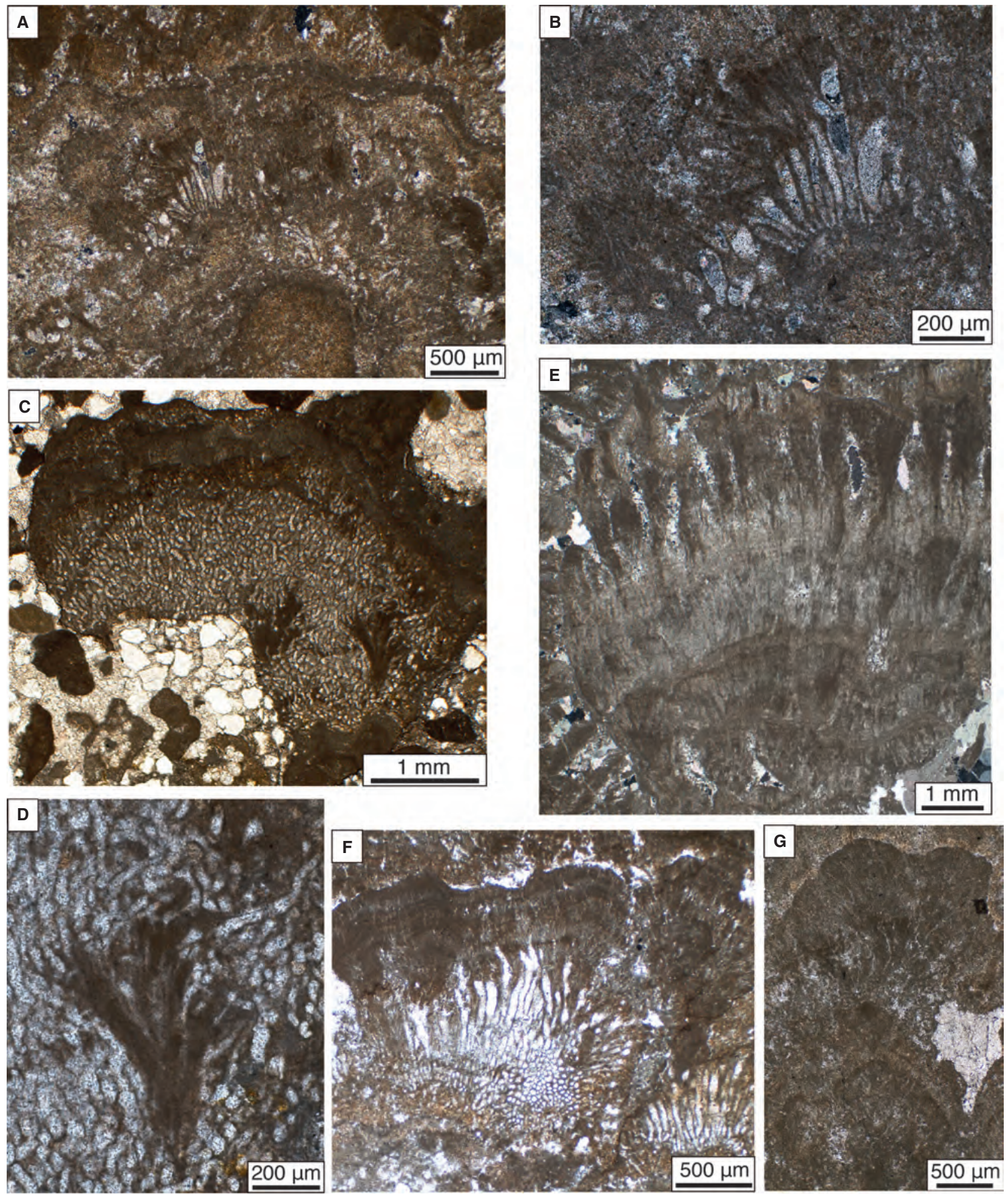

Fig. 7. Type 2 lamination and associated microbial bush-like bodies (optical microscope). (A) Wavy and irregular laminae with bush-like bodies. (B) Detail of (A) showing the bush-like arrangement of spar and micrite. (C) Fragment of laminated microbial deposit in a quartz-rich rudstone that evokes a mat of intertwined, closely packed filaments. (D) Detail of (C), showing a bush-like body of filaments. (E) Laminated bush-like body made of micrite and spar filaments. (F) Adjoining bush-like bodies forming a palisade. Note the evolution toward micrite-rich laminae at the top. (G) Two stacked bush-like bodies with micrite-rich laminae at their tops. 

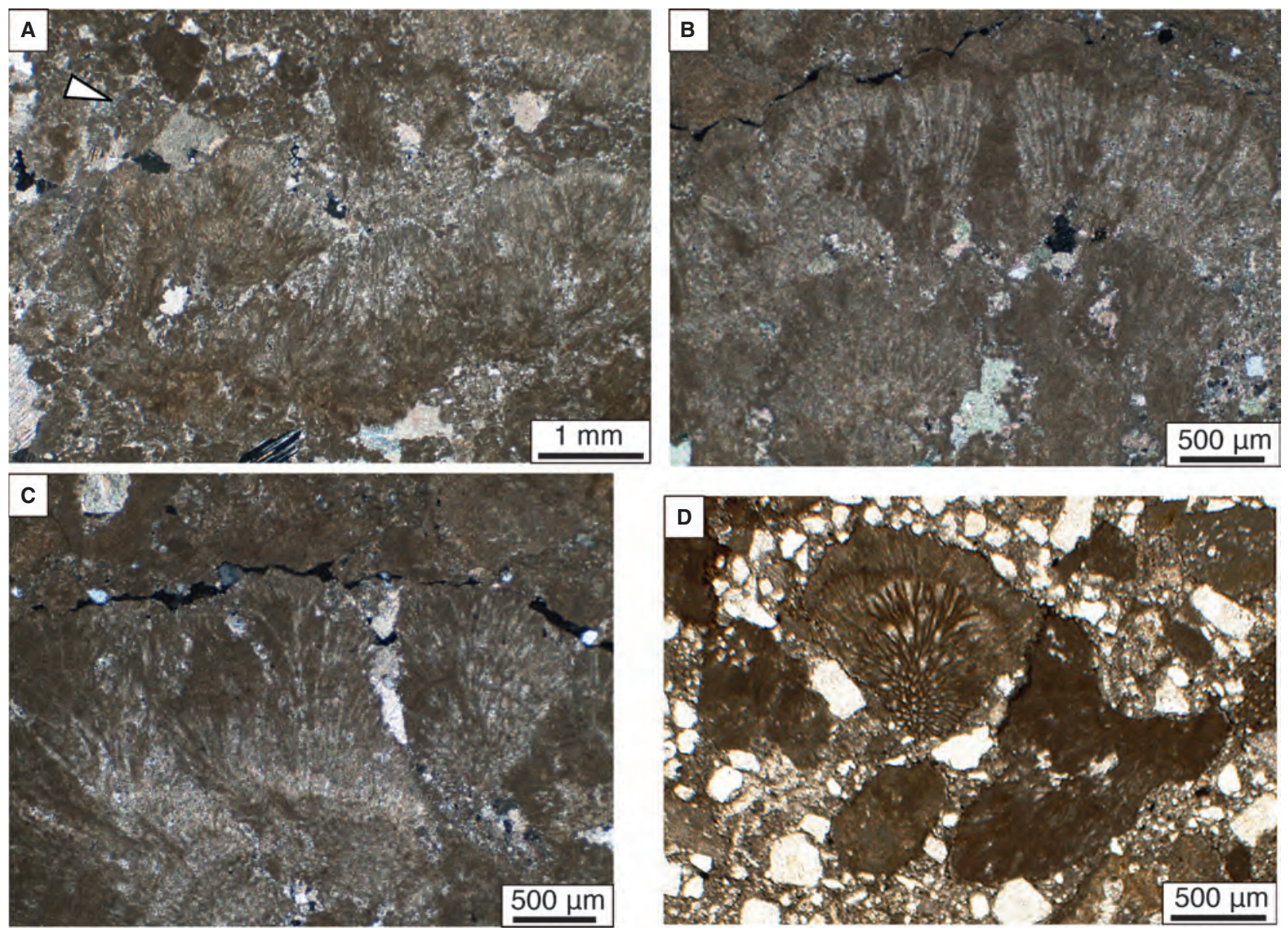

Fig. 8. Type 2 lamination and associated microbial fan-like bodies (optical microscope). (A) Irregular lamination made of adjacent fan-like bodies consisting of radially arranged filaments. Note the truncation by detrital deposits at the top (arrowed). (B) and (C) Detail of adjacent fan-like bodies consisting of radially arranged filaments. Note the lamination within the fan-like bodies. (D) Laminated fan-like body consisting of radially arranged filaments in a quartz-rich intraclastic rudstone.

Shapiro et al., 2009; Vázquez-Urbez et al., 2013). Fining-upward sequences result from waning energy conditions in channels, ending with the filling of the channels or ponds (Ordóñez \& García del Cura, 1983; Arenas et al., 2000; Meléndez \& Gómez-Fernández, 2000). The common presence of broken limestone particles provides evidence of higher energy episodes that resulted in partial abrasion and breakage of bed-load particles (i.e. oncoids) and the erosion of previous deposits formed in nearby ponded areas and fluvial channels (for example, micrite-rich deposits and stromatolites) and palustrine fringes (in situ calcite-coated stems). The fragments of such deposits were incorporated as bed-load into the oncoidal channels and/or deposited on inactive fluvial areas (ponded floodplain areas). Similar processes were interpreted from Tertiary sequences in north-east Spain (Arenas et al., 2007;
Vázquez-Urbez et al., 2013). The presence of extraclasts mixed with oncoids and intraclasts in certain sections suggests that these higher energy episodes also affected nearby siliciclastic deposits.

\section{Morphology and structure of oncoids}

Oncoids are present in all studied sections, either as the main allochem component or associated with fragments of stromatolites and massive micritic limestones. The size of oncoids varies from a few millimetres to $10 \mathrm{~cm}$ in length, and exceptionally up to $12 \mathrm{~cm}$ in length. Typically, they are between $3 \mathrm{~cm}$ and $8 \mathrm{~cm}$ long (Figs 4 and 5). The largest specimens are in the La Griega section; they can be subspherical, ovoid, cylindrical and discoid in shape. The most abundant examples are ovoid and cylindrical (Fig. 5). The outer surfaces range from smooth to slightly knobby. The nuclei are heter- 
ogeneous. In some cases, their shapes resemble plant stems and bivalve shells (Figs 4B, 5A, 5C and $5 \mathrm{D}$ ), the latter identified as freshwater bivalves (Delvene et al., 2013); these nuclei are filled with coarse spar calcite and less commonly are empty. In other cases, the nuclei consist of an intraclast (either massive or laminated microbial limestone), a mixture of intraclasts and extraclasts (mostly quartz) or siliceous extraclasts (Figs 5A, 5E, 5F and 6A).

The thickness of the oncoid coatings varies from a few millimetres to $6 \mathrm{~cm}$ and is mostly symmetrical around the nuclei (symmetrical or slightly asymmetrical cortices; Figs $5 \mathrm{~B}$ and $6 \mathrm{~B}$ ), although highly asymmetrical cortices exist (Figs 5C and 6A). In hand sample sections, the laminae are smooth or slightly wavy and mostly continuous (Fig. 5B and E). The outermost laminae tend to be smooth to gently wavy.

\section{Microscopic features of laminated}

microbialites (oncoids and stromatolites)

The entire and broken oncoids, calcite-coated phytoclasts and stromatolites (in situ and detached) exhibit similar microscopic characteristics in terms of lamination and microbial components. The differences between the studied sections are related to the relative abundance of distinct types of microbial structures (i.e. types of lamination and microbial bodies, as described below).

Typically, the lamination consists of alternating light (spar, microspar and micritic calcite) and dark (micrite calcite) laminae (Figs 6, 7A, 7F and 7G). Single light and dark laminae vary widely in thickness: light laminae are between $80 \mu \mathrm{m}$ and $1 \mathrm{~mm}$ thick, and dark laminae are between $30 \mu \mathrm{m}$ and $400 \mu \mathrm{m}$ thick. Light and dark composite intervals made of several single light and dark laminae are present (Figs 6C, 6D and 9A to C); the thickness of these composite intervals can be up to $1 \mathrm{~mm}$, and in certain cases up to several millimetres. These intervals can be distinguished with naked-eye observations of hand samples. Several oncoids include massive intervals of thrombolitic texture (up to $200 \mu \mathrm{m}$ thick) intercalated between the thinly laminated intervals. Within certain oncoids and stromatolites, fragmented laminae, along with quartz grains in some cases, and sharp vertical changes in colour occur (Figs 6A, 6C, 6D and 8A).

Based on the shape and mode of vertical arrangement of the laminae and the morphological types of microbial bodies, three broad types of lamination have been distinguished. Essen- tially, these correspond to the three lamination types defined by Arenas et al. (2007) in the Eocene and Oligocene continental microbialite deposits of Mallorca (Spain).

Smooth to slightly wavy thin lamination (type 1; light laminae: 80 to $300 \mu \mathrm{m}$ thick; dark laminae: 50 to $150 \mu \mathrm{m}$ thick) is not volumetrically abundant and mostly appears laterally and vertically associated with lamination of types 2 and 3. This type forms continuous intervals up to $1 \mathrm{~mm}$ thick (Fig. 6A to D). These intervals may cap wavy or domed structures. The microbial remains consist of single or grouped, mostly unbranched, micrite filamentous bodies that extend upward through one or two laminae (Fig. 6B and C). These bodies appear similar to the modern genus Phormidium. This type of arrangement has been found in oncoids of sections 1, 3 and 5 (see Fig. 1 for location).

Wavy or irregular thick lamination (type 2) exhibits a wide variety of lamina shapes: undulate, festooned and single and multiconvex (Figs 6E, 7A, 7F, 7G and 8A to C). The light laminae are $200 \mu \mathrm{m}$ to $1 \mathrm{~mm}$ thick, and the dark laminae are 100 to $400 \mu \mathrm{m}$ thick. Based on the arrangement of the microbial filamentous bodies, two types of microbial bodies are distinguished:

1 Bush-like bodies composed of thick tufts that may laterally coalesce forming palisade-like units, up to $7 \mathrm{~mm}$ high (Figs $6 \mathrm{E}$ and $7 \mathrm{~A}$ to $\mathrm{F}$ ). Some of these bodies resemble certain modern cyanobacteria of the genera Dichothix and certain filamentous algae, such as, perhaps, Vaucheria (Zamarreño et al., 1997; Freytet \& Verrecchia, 1998). Very similar structures in recent oncoids correspond to Schizothrix calcicola (Hägele et al., 2006). Bush-like bodies are particularly abundant in the oncoids of sections 3,4 and 5 .

2 Hemispherical, fan-like bodies (in sagittal cross-section) composed of radially oriented, mostly branched filamentous bodies (Fig. 8). The fans may appear isolated or laterally linked, and are up to $2.5 \mathrm{~mm}$ high. Their shape resembles certain modern cyanobacteria of the genera Rivularia and Gloeotrichia (Freytet \& Verrecchia, 1998; Caudwell et al., 2001). Similar radial filament arrangements in modern oncoids correspond to Rivularia haematites (Hägele et al., 2006; Pentecost \& Franke, 2010). This type of microbial body is present in all studied sections.

Both the bush-like and fan-like microbial bodies can be laminated, featuring alternating 
light and dark parts that generally grade outward into darker and more micritic laminae (Figs 7E, 7F and 8). A similar lamination tendency was described by Caudwell et al. (2001) and Hägele et al. (2006) in microbial bodies composed of radially oriented filaments.

Domed, pseudocolumnar and columnar lamination (type 3) consists of alternating laminae of light microspar and spar (50 to $300 \mu \mathrm{m}$ thick) and dark micrite (50 to $100 \mu \mathrm{m}$ thick). The base of these structures can be made of peloidal micrite. The laminae are single convex, multiconvex or closed parabolic, discontinuous in domes and columns and semicontinuous in pseudocolumns (Fig. 9). The domes and columns are up to $1.2 \mathrm{~mm}$ high. Isolated or loosely grouped, unbranched micrite filamentous bodies extend across two to four laminae, with a roughly radial orientation (Fig. 9C to G). These micrite bodies correspond to cyanobacterial remains that resemble the modern genus Calothrix (Hägele et al., 2006).

The lamination of type 2 is more common at the base of the microbialites, whereas the lamination of type 3 is more common toward the outer part, although different arrangements exist. The lamination of type 1 is interlayered with both types 2 and 3 .

Most oncoids show a distinctive arrangement consisting of bush-shaped and fan-shaped bodies or domed and columnar structures at the base, which gradually pass upward into thinner, more continuous and smoother laminae, in some cases ending up with the type 1 lamination (Figs 6C, 6D, 7F and 7G). In general, the lower part of every unit is more porous and/or lighter in colour (microspar-rich and light micrite-rich) than the upper part, which tends to be denser and/or darker (micrite-rich) in colour. Up to five consecutive units can be seen in some oncoids.

\section{Oncoid-intraclast rudstones, packstones and wackestones (Li)}

This facies forms tabular, undulate and lenticular strata, in places with channel-shaped bases. These strata can be decimetre to $1.3 \mathrm{~m}$ thick (Figs 2B, 2C and 3C to F). These strata are usually grouped into tabular units (up to $2.5 \mathrm{~m}$ thick) and generally overlie the oncoid rudstones. Fining-upward sequences, based on the size of allochems and/or the abundance of matrix, are observed in the Vega section (Fig. 2C), where rudstone-packstone-wackestone/floatstone suc- cessions, decimetre to $1.3 \mathrm{~m}$ thick, are present. However, certain strata feature the largest intraclasts at their tops (for example, the Abeu section). In that section, the carbonate unit composed of this facies has a darker grey colour at the top (Fig. 3F).

This facies is composed of intraclasts and minor oncoids (complete and broken) of highly variable size and shape (Fig. 10A to C). The intraclasts are varied in nature and include laminated microbial deposits (oncoids and probably stromatolites), single or grouped bush-like and fan-like microbial bodies, and dark grey to light grey coloured massive and peloidal micrite and intraclastic limestones (Fig. 10E to F). The intraclasts, subrounded to subangular, range from millimetre to $20 \mathrm{~cm}$ long (exceptionally, $30 \mathrm{~cm}$ long). The most angular are those of the laminated microbial particles. External moulds and fragments of coaly vegetal matter (mostly stems) can reach $50 \mathrm{~cm}$ long. The complete oncoids are millimetre to $12 \mathrm{~cm}$ long. The matrix between these components is micrite, and in places consists of intraclast wackestone. Variable amounts of spar cement are present. Detrital siliceous grains (mostly of quartz), up to 1 to $2 \mathrm{~mm}$ in diameter, can be abundant in the matrix of certain samples (for example, sections 1 and 3; Fig. $10 \mathrm{E}$ and F). Occasionally, yellowish to brownish rounded particles of siliceous mudstones are present.

This facies formed through deposition in fluvial channels and overbank areas, including ponded zones. The allochems provide evidence of erosion of earlier carbonate deposits formed in nearby ponded areas (micrite-rich deposits and stromatolites), the palustrine fringes (in situ coated stems) and fluvial channels (oncoidal deposits). The high quantity of extraclasts mixed with intraclasts in certain sections supports the hypothesis that erosion affected nearby siliciclastic deposits as well (for example, sandy and silty sediments). During high-discharge periods, carbonate fragments and siliceous grains were incorporated as bed-load into the channels and/or deposited in the interchannel areas. Fining-upward deposits represent the fill of channels in waning conditions; the coarser deposits at the top of certain beds correspond to high-discharge conditions during flooding on overbank areas. Similar processes were interpreted from Tertiary sequences in north-east Spain (Arenas et al., 2007; Vázquez-Urbez et al., 2013). The deposits composed dominantly of 

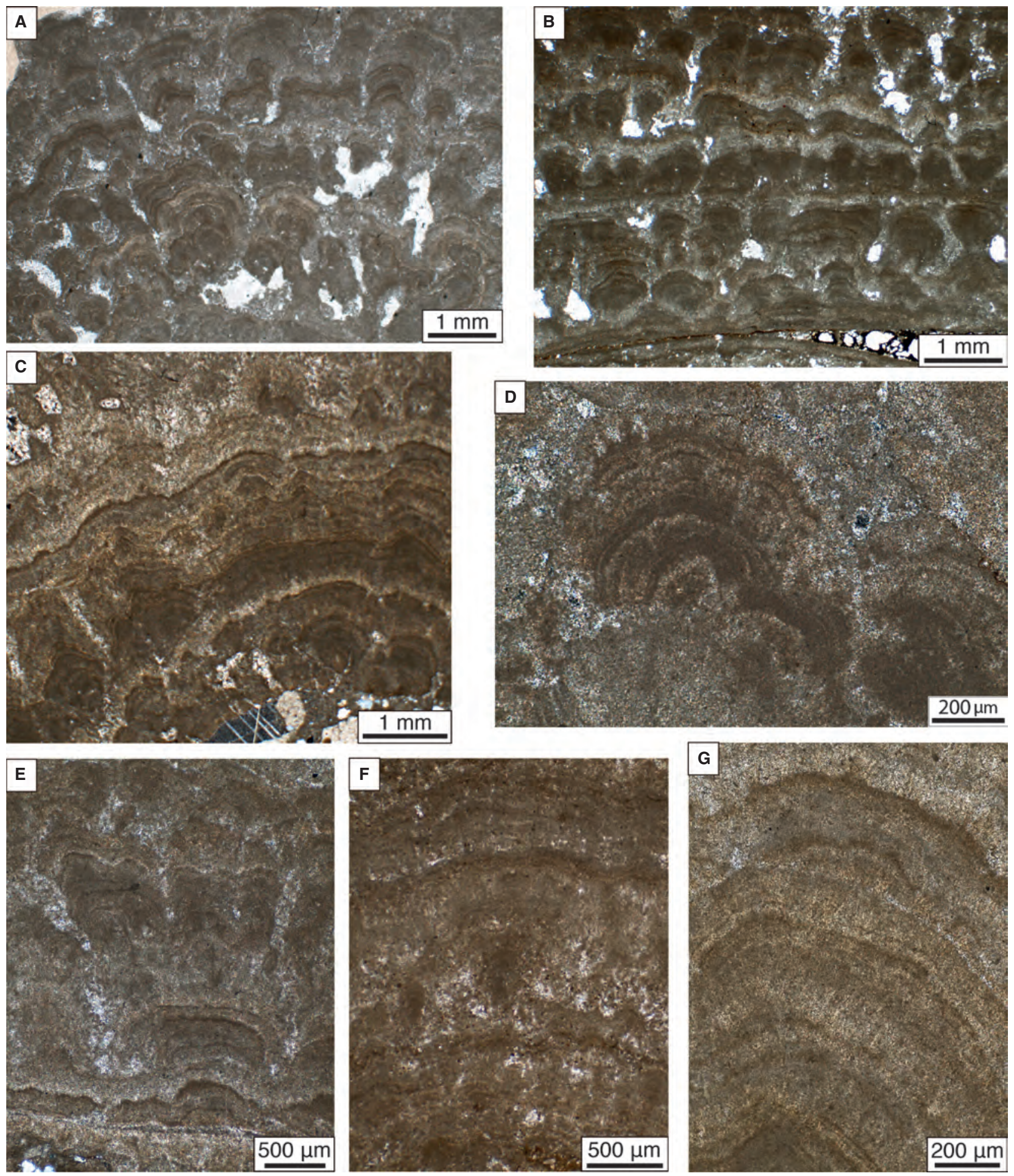

Fig. 9. Type 3 lamination and associated microbial fan-like bodies (optical microscope). (A) Stacked domes with continuous and discontinuous laminae. (B) Stacked intervals composed of laminated domes. Note the lateral variation in thickness of one of them. (C) Upward evolution from domed lamination at the base toward continuous, slightly wavy lamination at the top. (D) Detail of the laminae in the domes. Note the presence of loose micrite filaments with a radial orientation. (E) Upward evolution from flat and slightly domed to domed to columnar lamination. Note the presence of loose micrite filaments subperpendicular to the laminae. (F) Upward evolution from slightly domed to slightly wavy lamination with darker and micrite-rich laminae toward the top. Note the existence of radially arranged micrite filaments. (G) Detail of the lamination in a column, with micrite filaments subperpendicular to the laminae. 

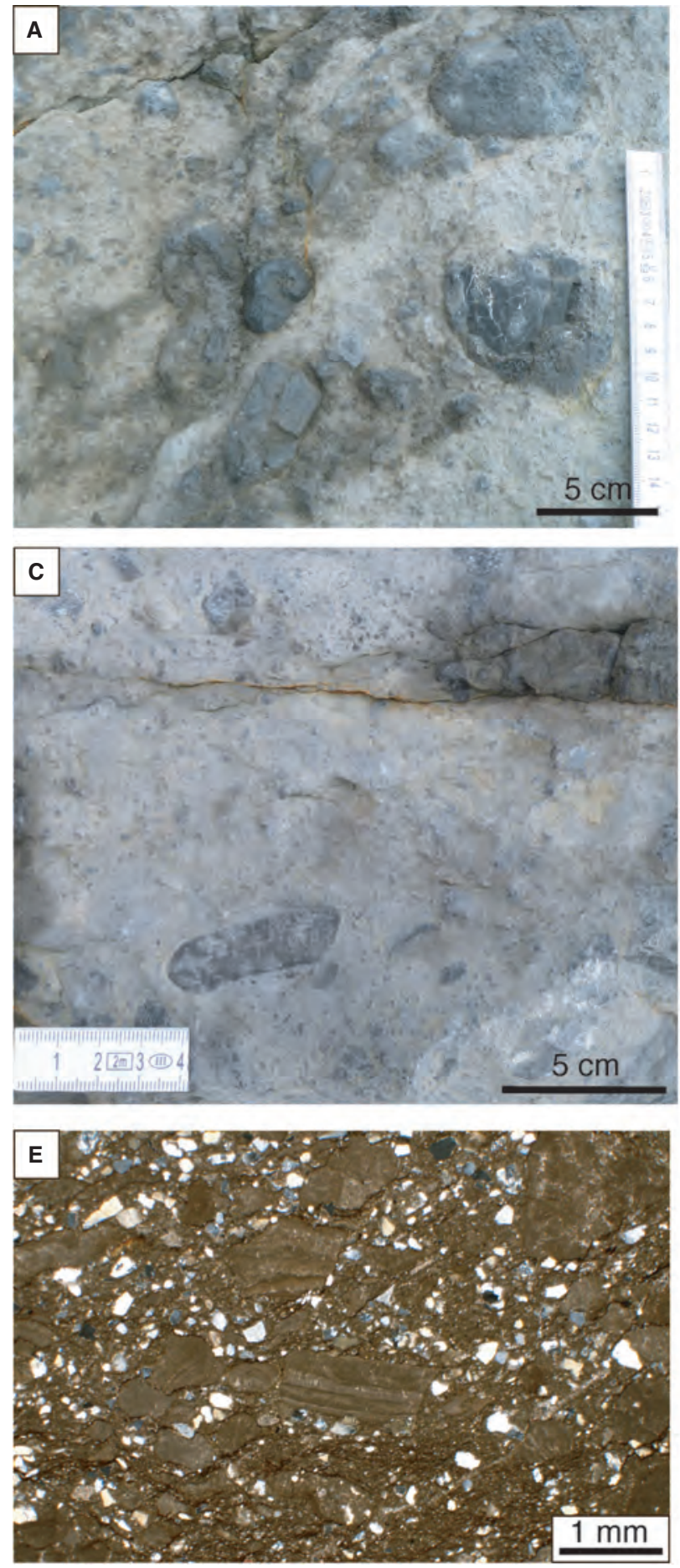
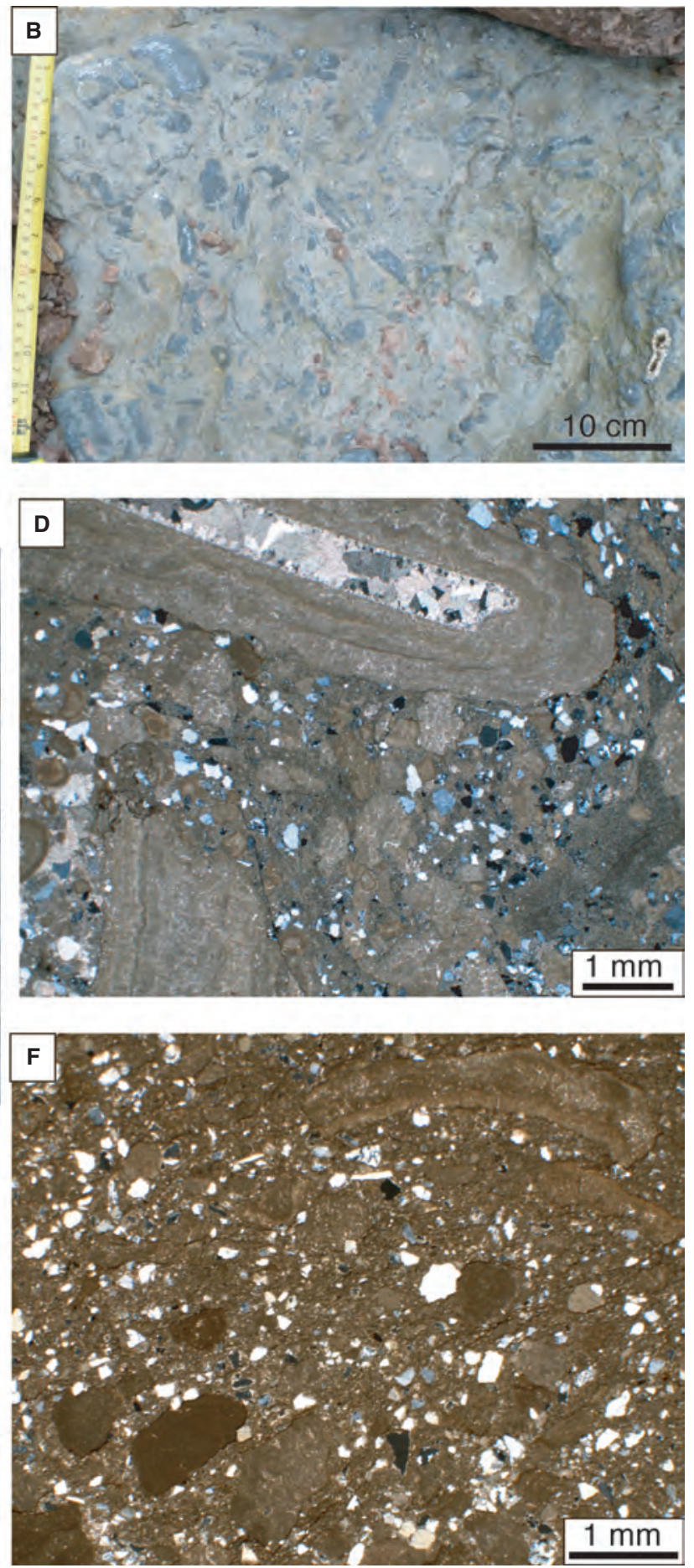

Fig. 10. Field views (A to $C$ ) and photomicrographs (optical microscope, D to F) of oncoid-intraclast rudstones and packstones. (A) and (B) Plan view of a rudstone. (C) Highly heterometric intraclasts from base to top. (D) Massive and laminated, mostly angular, intraclasts and oncoid (laminated calcite coating a stem). Note the abundance of detrital quartz grains. (E) and (F) Packstones containing intraclasts, mostly stromatolitic or oncolitic in (E) and micritic in $(\mathrm{F})$, with detrital quartz grains.

intraclasts represent higher energy conditions during which oncoid formation was reduced. The dark grey colour at the top of certain deposits suggests stagnation during the final filling process of abandoned channel reaches and pools. Darker grey-coloured intraclasts probably 
formed from erosion of organic-matter-rich stagnant zones (Platt, 1989).

\section{Oncoid-charophyte bioclast-intraclast packstones and rudstones (Lich)}

This facies forms the base of gently lenticular strata that are up to $1 \mathrm{~m}$ thick and are mostly composed of oncoid rudstones in the Vega section (Figs 2C, 3C and 3D). The attributes of intraclasts and oncoids of this facies are identical to those described above, although the overall size of these allochems is smaller (submillimetre to $2 \mathrm{~cm}$ long). Commonly, micritic intraclasts are dominant. The charophyte remains are observed as cross-sections of stems coated by calcite, both laminated and non-laminated, scattered among the other allochems (Fig. 11A and $\mathrm{B}$ ).
These deposits represent deposition in shallow fluvial channels and overbank areas following erosion of previous sediments formed in the adjacent ponded areas where charophytes could dwell and oncoids could form. Alternatively, these deposits could have formed through deposition in ponded areas after lacustrine sediment remobilization due to overflowing of oncoid-bearing channels (Arenas et al., 2007).

\section{Intraclast-bioclast wackestones (Lib/Lbi)}

The deposits of this facies are not abundant and have only been found in the Vega section (Fig. 2C), forming centimetre-thick to decimetrethick beds interbedded within the intraclastic limestones (Li). In one case, facies Lib constitutes the upper part of a $0.7 \mathrm{~m}$ thick body with a rather planar base (with sauropod tracks) and
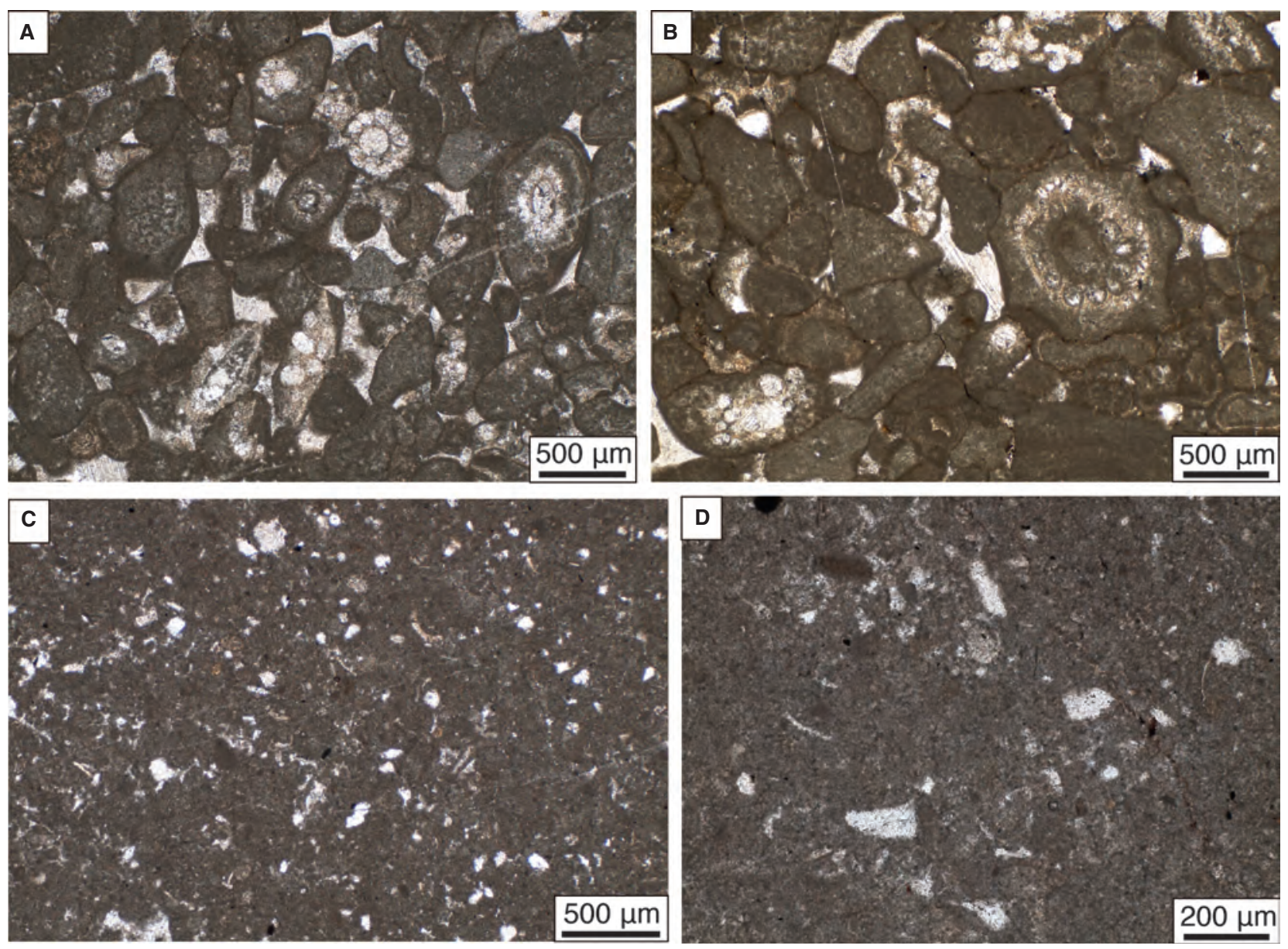

Fig. 11. (A) and (B) Photomicrographs (optical microscope) of packstones and rudstones containing massive micritic intraclasts, charophyte stems and small oncoids. Note that some charophyte stems are coated by massive and laminated micrite. (C) and (D) Photomicrographs (optical microscope) of wackestones containing intraclasts and bioclasts (bivalves and ostracods), with scattered quartz grains. 
an undulate top (Fig. 3D) made of packstones/ rudstones containing heterogeneous particles (carbonate intraclasts, detrital quartz and red to orange siliceous mudstone fragments). This bioclast-intraclast wackestone exhibits nodulization.

Depending on the abundance of intraclasts, this facies is termed Lib (intraclastic and bioclastic) and Lbi (less abundant intraclasts). Locally, packstones and mudstones-wackestones are present. Intraclasts are submillimetre to millimetre long, mostly rounded to subangular grains of massive and peloidal micrite. The bioclasts consist of ostracods (separate valves) and bivalve molluscs (broken shells). Detrital quartz grains are present in small amounts (Fig. 11C and D).

This facies formed in small shallow lakes (shallow ponded areas) in which ostracods and freshwater bivalves dwelled (Platt, 1989). These areas developed after, or were affected by, high-discharge events (for example, channel overflow) that involved partial erosion of deposits of the carbonate system and the siliciclastic floodplain that had been subject to intense desiccation (with the development of palaeosols). In the Oligocene deposits of Mallorca, bioclastic facies at the top of finingupward sequences were interpreted as the final fill stage of oncoidal channels with lacustrine sedimentation (Arenas et al., 2007). The marginal lacustrine facies of the Morrison Formation (Late Jurassic, western USA) include intraclastic and bioclastic limestones with pedogenic features that represent deposition on low-gradient lake margins and in secondary ponds subject to desiccation and reworking (Dunagan \& Turner, 2004).

\section{Marlstones and marly limestones (M)}

These form thin tabular beds (commonly up $5 \mathrm{~cm}$ thick, and exceptionally $0.7 \mathrm{~m}$ thick), generally structureless, and are interbedded with strata of intraclastic packstones (Figs 2B, 2C and 3C). Marlstones and marly limestones are greycoloured and can contain millimetre-long scattered intraclasts of dark grey limestones. In some cases, root traces are present.

Marls and marly lime mud formed as a result of surface water input with fine siliciclastic detritus into small lakes or ponded areas, which caused a rise of water level, followed by the settling of the particles (Dunagan \& Turner, 2004); increasing lime mud deposition resumed after the inflow waned. Hydrophilous plants could dwell in such muddy areas (Platt, 1989; ArenasAbad et al., 2010).

\section{FACIES ASSOCIATIONS AND SEDIMENTARY F ACIES MODEL}

\section{Facies associations}

Four main facies associations (FA) were distinguished. Three of these represent subenvironments and processes of the studied carbonate system (Fig. 12A): (i) channels and overbank areas; (ii) channels/overbank areas to lacustrine areas; and (iii) middle-distal alluvial fan areas. Facies association 1 reflects deposition in lowsinuosity channels, mostly with oncoids and minor intraclasts, which flowed through a tufapalustrine area. Stromatolites represent the final fill in lower energy conditions. Higher discharge processes that caused channel overflow and erosion of interchannel areas produced intraclastic deposits. The alternation of these two facies (Lo and $\mathrm{Li}$ ) thus record changing energy conditions. Facies association 2 records the development of ponded areas both in abandoned channelized areas and depressions in the overbank/interchannel areas. The ponds were habitat for freshwater bivalves, charophytes and ostracods (facies Lib, Lbi and Lich) and could be affected by erosion during higher discharge events. Facies association 3 corresponds to deposition by sheet-like and gently channelized flows from alluvial fans that entered the carbonate fluviallacustrine system, resulting in deposition of calcareous and minor siliciclastic extraclasts and carbonate allochems as tabular bodies. After such alluvial events (represented by facies Co), carbonate deposition resumed (facies Lo and Li). Similar facies associations have been described by Vázquez-Urbez et al. (2013) in the Ebro Basin (Spain). Finally, facies association 4 (inferred from García-Ramos et al., 2010a) represents coarse siliceous sand deposition by high-sinuosity channels (facies St) in a wide floodplain (facies Fm) that experienced desiccation and pedogenesis (Platt, 1995; Gutierrez \& Sheldon, 2012).

\section{Sedimentary facies model}

Carbonate sedimentation in the Vega Formation took place in shallow, low sinuosity channels and pools within a marshy area (Fig. 12B) that, 
A

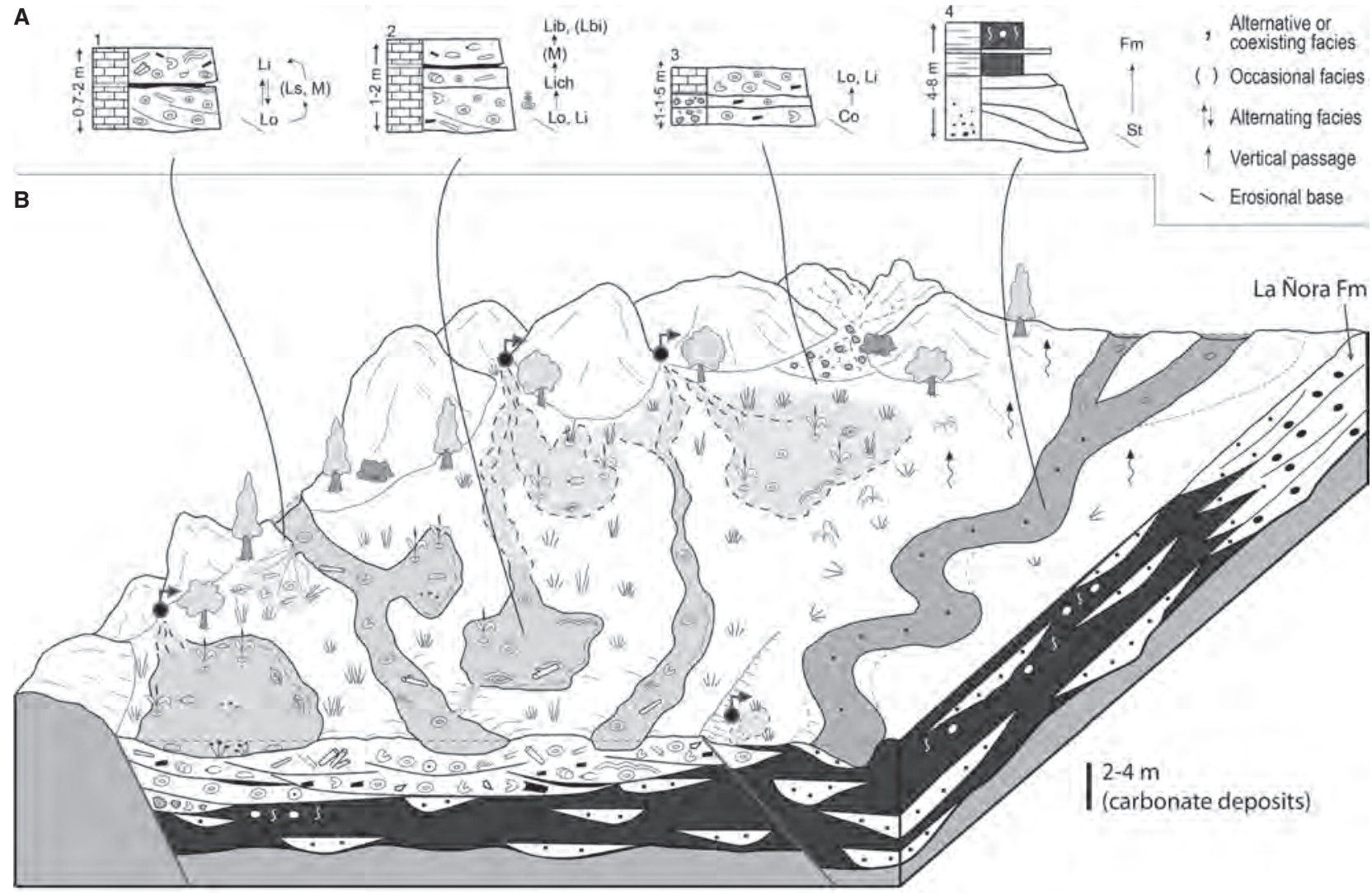

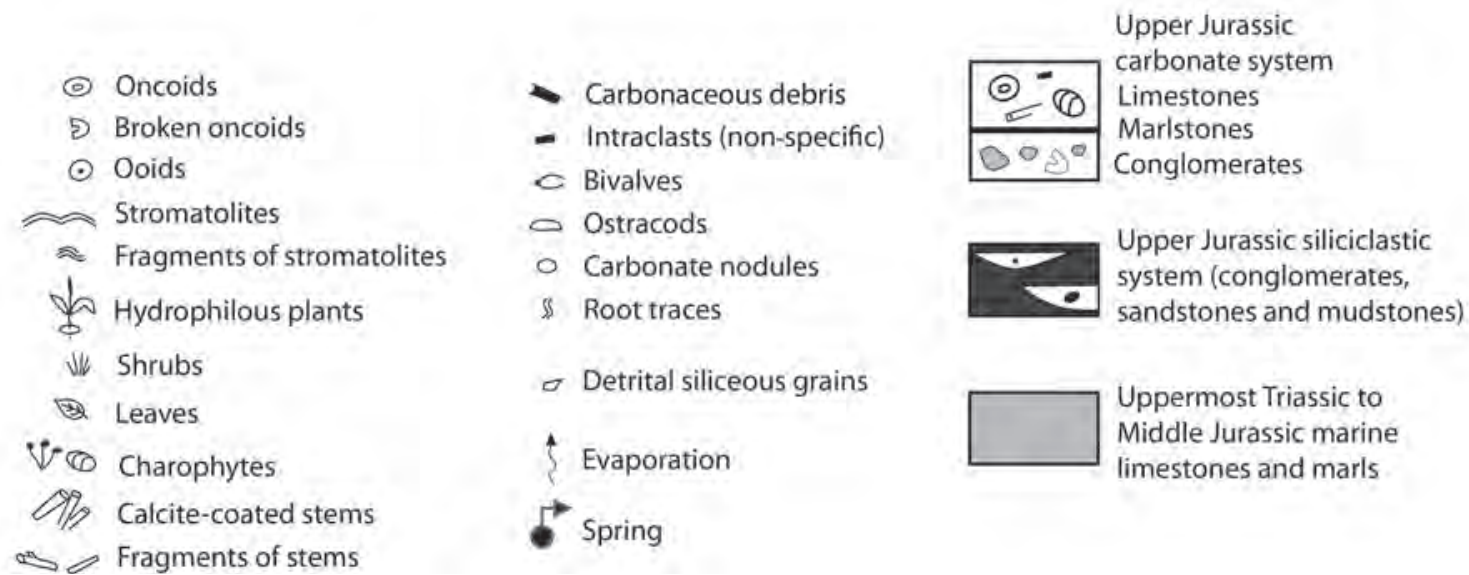

Fig. 12. Facies associations (A) and the sedimentary facies model (B) of the fluvial-lacustrine carbonate deposits of the Vega Formation. Explanation in the text - Facies association 4 is inferred from information of García-Ramos et al. (2010a). Labels of carbonate facies are those defined in this work. St: siliceous sandstones with cross-stratification. Fm: siliceous mudstones.

as a whole, might be envisaged as a wetland within the east/north-eastward-flowing siliciclastic fluvial system. A broadly similar scenario was proposed for the Kimmeridgian oncoid-rich limestones of Portugal (Leinfelder, 1985), albeit without the connection to sea water and associated salinity variations in the Vega case. The studied carbonate fluvial-lacustrine system of Asturias was characterized by the large-scale development of oncoids and tufaceous palustrine facies, and fits the classification of a low-gradient fluvial carbonate system (cf. classification of Arenas-Abad et al., 2010). Commonly, a high content of $\mathrm{HCO}_{3}{ }^{-}$ and $\mathrm{Ca}^{++}$in the water is required to form these facies, and these components are generally supplied by carbonate-hosted aquifers (Ordóñez \& 
García del Cura, 1983; Hernández Gómez, 2000; Pedley, 2009; Arenas-Abad et al., 2010; VázquezUrbez et al., 2013). Nonetheless, the sources for carbonate sediment also include land transport of carbonates as bed-load, suspended and dissolved particles from older calcareous rocks, which might be particularly important in distal areas of fluvial systems (Gierlowski-Kordesch, 1998). Many carbonate deposits described in distal areas and floodplains of fluvial systems correspond to lacustrine and palustrine environments in which $\mathrm{HCO}_{3}{ }^{-}$and $\mathrm{Ca}^{++}$ions are primarily supplied through surface flows (Pla-Pueyo et al., 2009; Gierlowski-Kordesch et al., 2013). The distribution of the studied carbonate deposits in the present interior area (sector 3; Fig. 1B) along normal faults that affected the uppermost Triassic to Middle Jurassic rocks in the Late Jurassic suggests the existence of water springs from an uppermost Triassic-Lower Jurassic rock aquifer emerging from the fractured zone (García-Ramos et al., 2010b). Similarly, in the outcrops along the modern coast (for example, in La Griega, section 1, Fig. 1B), the close relationship between certain channelshaped deposits and normal faults also suggests water springs as the main water source of the carbonate system (García-Ramos et al., 2010b). The association of water springs and faults was also proposed by Hernández et al. (1998) for the Kimmeridgian-Berriasian travertines to the south-east of the studied area. Evans (1999) suggested a structural control for the occurrence of Eocene tufas and travertines in the Chaldron Formation (USA), in which the groundwater discharge was influenced by fractures.

The extent of the studied fluvial-lacustrine carbonate system is difficult to estimate given the physical disconnections of the outcrops due to tectonics and the scarcity of outcrops, which impedes precise correlation among the sections. The deposits crop out in areas that are more than $50 \mathrm{~km}$ apart.

The oncoids formed in slow-moving water conditions in shallow, wide channels and interchannel and intrachannel ponds subject to continuous or episodic water movement. The continuous and isopachous lamination, without lateral changes in the type of lamination around the oncoids, suggest continuous or episodic movement of the oncoids that allowed cyanobacteria and small algae to grow continuously on all sides of the oncoids. The asymmetrical or discontinuous growth observed in certain oncoids probably resulted from longer periods of motionlessness (Freytet \& Plaziat, 1982). Moreover, the presence of sharp vertical changes in colour and erosional features within the microbial lamination indicate periods of interruption in oncoid accretion (for example, as recognized in the Campóo Group, Upper Jurassic-Lower Cretaceous of northern Spain by Hernández Gómez, 2000) which could be linked to periods of both desiccation and increased energy.

The existence of vegetated areas (hydrophilous grassy plants) in the channels and interchannel ponds is suggested by the nature of the oncoid nuclei (in most cases, moulds of plant stems) and the presence of calcite-coated phytoclasts (fragments of calcite-coated stems) in the oncoidal and intraclastic facies. The submerged parts of these plants were coated by calcite with the same structure of microbial lamination as in the oncoids. During storms or increased discharge, coated and uncoated parts of plants would be broken and deposited nearby, and the coated fragments would be preserved as phytoclasts. Alternatively, coated and uncoated plants also served as nuclei for the development of oncoids (Diéguez et al., 2009; Vázquez-Urbez et al., 2012). However, the deposits made of in situ plants (i.e. stem boundstones) are almost absent, which suggests the common occurrence of erosion processes in these marshy areas. Erosion events are also suggested by the abundance of broken particles of different nature (oncoids, stromatolites and massive limestones) that are mixed with entire oncoids and that probably resulted from increased discharge and overbank flooding. High discharge would affect ponds in which the bioclastic facies formed. Together, these observations indicate the great mobility and shallowness of the carbonate fluvial channels and common overflowing (FA 1, Fig. 12).

Ponds that developed close to springs and in interchannel and intrachannel areas would be loci for stromatolites to form in calm conditions, possibly as the final fill deposits. However, the scarce stromatolite outcrops prevent an accurate interpretation. In the ponded areas, ostracods, freshwater bivalves (Unionoids) and/or charophytes could dwell, some of which acted as nuclei for oncoids. Some of these areas were fed directly from springs and temporarily connected to running water channels. In other cases, the ponds developed after shallowing and/or abandonment of the oncoid-bearing channels (FA 2, Fig. 12; Leinfelder, 1985; Arenas et al., 2007). In either case, the deposits formed in these ponded areas (lime mud with bioclasts) were affected by remobilization and/or erosion, as suggested by 
the common mixture of intraclasts and bioclasts in facies Lib, and the nature of intraclasts and certain oncoid nuclei of facies Li.

In addition, small alluvial fans (represented by facies Co) were sourced from the uplifted areas of Lower and Middle Jurassic rocks occurring near the carbonate fluvial-lacustrine system. Middle and distal alluvial deposits reached the deposition areas of the system during moderate to high-discharge periods, which caused extensive erosion of former and concurrent deposits of both the carbonate system and the siliciclastic system (FA 3; Fig. 12B).

The presence of intraclasts (composed of microbialites and bioclastic limestones) and extraclasts in certain carbonate deposits indicate that the carbonate system experienced episodic increases in discharge that resulted in extensive erosion. During high-discharge periods, erosion affected not only the fluvial-lacustrine carbonate deposits, but also the deposits of the coexisting east/north-eastward flowing siliciclastic fluvial system. This caused the incorporation of siliceous particles into the carbonate deposits. Together, these facts suggest that the different subenvironments of the carbonate fluvial-lacustrine system experienced rapid lateral changes, which were probably conditioned by the rather variable hydrology linked to the precipitation pattern. The alluvial fan sediments prograded over the fluvial-lacustrine carbonate system during episodes of higher discharge.

The adjacent siliciclastic floodplain, far from the surface water supply, experienced strong desiccation and pedogenesis (Gutierrez \& Sheldon, 2012). Groundwater derived from the uppermost Triassic-Lower Jurassic rock aquifer provided $\mathrm{HCO}_{3}{ }^{-}$and $\mathrm{Ca}^{++}$for carbonate soil formation.

\section{SIGNIFICANCE OF LAMINATION IN MICROBIALITES}

Lamination in microbialites is commonly described on the basis of the alternation of laminae of different colour, crystal size and/or porosity, and the presence of microbial attributes (Monty, 1976; Golubic, 1991; Riding, 2000; Seong-Joo et al., 2000). However, lamination can be observed at different scales, which makes interpretation of the lamination in terms of environmental and temporal significance more complex (Storrie-Lombardi \& Awramik, 2006; Petryshyn et al., 2012). In addition, diagenesis may overwhelm the original textural attributes (Park, 1976; Golubic et al., 2008).

The different lamination types associated with distinct morphological types of microbes and microbial arrangement (i.e. types 1, 2 and 3 in this work) reflect the response of microbial growth and concurrent mineral precipitation to episodic, in some cases iterative, changes in a wide array of physical and chemical parameters over different time spans. Single laminae with uniform textures (for example, in the lamination of types 1 and 3, Figs 6B, 9D and 9G), as defined through microscopic observations, constitute the simplest single units in this work. In general, this type of simple lamination/laminae may result from seasonal and intraseasonal changes in environmental parameters (chiefly, biological and physico-chemical parameters dependent on temperature, insolation and/or precipitation), as discussed by Seong-Joo et al. (2000), Merz-Preiß \& Riding (1999) and Riding (2000). However, simple lamination has also been reported as annual (Petryshyn et al., 2012). The sublaminae that compose certain laminae (for example, within the bush and fan-shaped microbial bodies in lamination of type 2; Figs 7E and 8) may thus reflect shorter intraseasonal variations linked to biological growth (for example, related to light intensity and turbulence; Seong-Joo et al., 2000; Caudwell et al., 2001; Noffke \& Awramik, 2013).

Moreover, in the study case, a composite lamination results from the alternation or succession of intervals consisting of several alternating light and dark simple laminae, in which each composite interval (i.e. composite lamina) is dominated by either: (i) light, microsparitic, sparitic and/or porous laminae; or (ii) dark, micritic and/or dense laminae (Fig. 6C and D). For the most part, this composite lamination corresponds to the lamination pattern distinguished without direct magnification in the studied Jurassic samples (Fig. 5B, C and D). This style of composite lamination may reflect seasonal, annual or pluriannual cycles related to variations in climatic and hydrological parameters (e.g. Andersen et al., 2011; Petryshyn et al., 2012; Arenas et al., 2014). The textural analysis and deposition rates obtained from modern oncolites and stromatolites in fluvial carbonate systems (from 0.4 to $1.7 \mathrm{~cm} \mathrm{yr}^{-1}$ in stromatolites) indicate that a number of simple laminae can form in several months (Ordóñez et al., 1980; Drysdale \& Gillieson, 1997; Gradziński, 2010; Vázquez-Urbez et al., 2010; Manzo et al., 2012; Arenas et al., 2014) which is consistent with the above temporal interpretation of the 

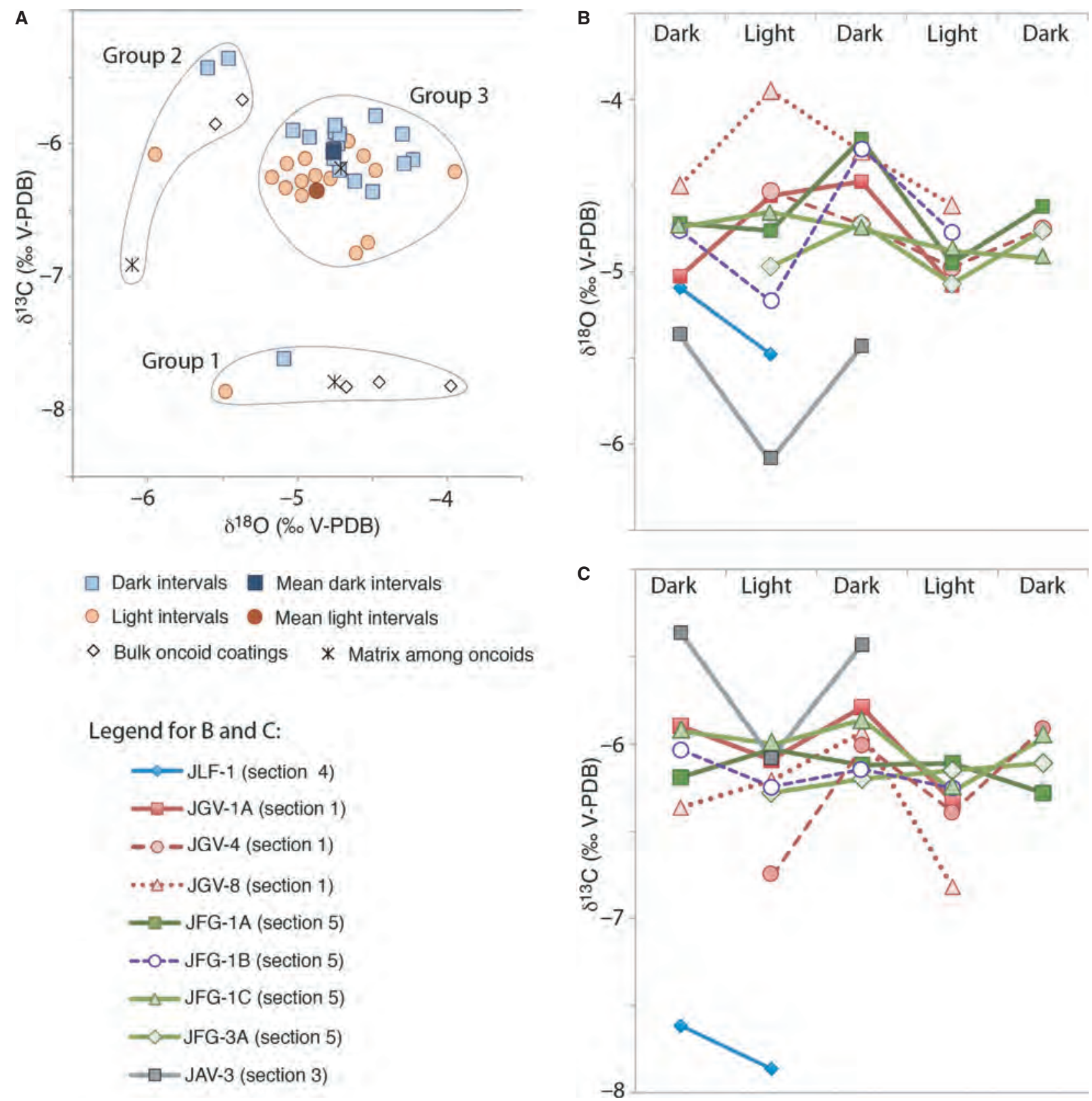

$$
\begin{aligned}
& \text { Legend for B and C: } \\
& - \text {-JLF-1 (section 4) } \\
& -0-J G V-1 A \text { (section 1) } \\
& \cdots-J \text { JGV-4 (section 1) } \\
& --J \text { section 1) } \\
& -- \text { JFG-1A (section 5) } \\
& --J \text { JFG-1C (section 5) } \\
& - \text { section 5) } \\
& \rightarrow-J A G-3 A \text { (section 5) }
\end{aligned}
$$

Fig. 13. Stable-isotope composition $\left(\delta^{13} \mathrm{C}\right.$ and $\left.\delta^{18} \mathrm{O}\right)$ of microbialite samples from the Vega Formation. (A) $\delta^{13} \mathrm{C}$ versus $\delta^{18} \mathrm{O}$ of all analysed samples $(n=46)$. Values of dark and light intervals are distinguished (sampled intervals correspond to simple and composite laminae, as described in the text). Group 1: La Fumarea (JLF; section 4); Group 2: Lastres and Abeu (JLV-1 and JAV-3; sections 1 and 3); Group 3: rest of sections (La Griega, JGV-1, 4, 8; Lastres, JLV-2, section 1; Fuente del Gato, JFG-1A, 1B, 1C and 3A; section 5). (B) $\delta^{18} \mathrm{O}$ values of successive dark and light intervals in oncoids. (C) $\delta^{13} \mathrm{C}$ values of successive dark and light intervals in oncoids. Legend of sample labels in (B) and (C): JLF: section 4; JGV: section 1; JFG: section 5; JAV: section 3. See Fig. 1B for location and Appendix 2 for stable-isotope values.

ancient microbial lamination. In the studied Jurassic microbialites, most composite laminae range from 0.5 to $8 \mathrm{~mm}$ thick. Therefore, a seasonal duration of the dark and light composite laminae is plausible in such microbialites.

\section{STABLE-ISOTOPE COMPOSITION}

A careful selection of samples, avoiding cements and recrystallization areas, was carried out from several oncoid rudstones and stromatolites to 
obtain environmental information from the stable-isotope compositions. The samples selected for stable-isotope analyses correspond to successive dark and light intervals in the microbialites and, in a few cases, to matrix between the oncoids and bulk oncoid coatings. Most sampled intervals, each $c a 0.5$ to $8 \mathrm{~mm}$ thick, contain several laminae, thus corresponding to composite laminae (as defined above). No distinction was made between the three types of lamination. Light intervals are commonly more porous, thicker and/or correspond to a dominance of microspar and light micrite laminae; dark intervals are commonly denser, thinner and/or correspond to a dominance of dark micrite laminae (Fig. 5B, C and E). In other cases, the sampled intervals mostly correspond to single laminae. Therefore, the sampled intervals represent different time spans, probably from seasonal (which would be the case for most of them) to pluriannual cycles.

\section{Results}

The $\delta^{13} \mathrm{C}$ values exhibit a wide range of variation (from -5.43 to $-7.86 \%$ ), with a mean value of $-6 \cdot 34 \%$ V-PDB. The $\delta^{18} \mathrm{O}$ values range from -3.95 to $-6 \cdot 10 \%$, with a mean value of $-4.82 \%$ V-PDB (Fig. 13A; Table 2; Appendix 2). Three separate groups can be differentiated (Fig. 13A): (i) the group of La Fumarea samples (group 1; section 4), with lower $\delta^{13} \mathrm{C}$ values and a wide range of $\delta^{18} \mathrm{O}$ values; (ii) the group containing Abeu (JAV-3; section 3) and Lastres (JLV-1; section 1) samples (group 2), with lower $\delta^{18} \mathrm{O}$ values and a wide range of $\delta^{13} \mathrm{C}$ values; and (iii) the group containing the rest of samples (group 3; JGV and JLV-2, section 1; JFG, section 5), with a smaller range of $\delta^{13} \mathrm{C}$ and $\delta^{18} \mathrm{O}$ values. For each group, no differences in isotopic composition of the different components analysed (oncoid coatings, stromatolites and matrix between oncoids) were observed, except for the lower $\delta^{18} \mathrm{O}$ values of the matrix in group 2. Correlation between $\delta^{13} \mathrm{C}$ and $\delta^{18} \mathrm{O}$ (Table 2) is almost absent in groups $1(r=-0 \cdot 19 ; n=6)$ and $3(r=-0.02 ; n=34)$, but it increases for group 2 $(r=0.86 ; n=6)$. Most samples from the light intervals display lower $\delta^{13} \mathrm{C}$ and $\delta^{18} \mathrm{O}$ values than the dark intervals, although exceptions exist (Fig. 13A to C; Table 2).

\section{Environmental interpretation}

Overall, $\delta^{13} \mathrm{C}$ and $\delta^{18} \mathrm{O}$ values of the studied Jurassic samples are within the range of values obtained in laminated microbialites of other fluvial and fluvial-lacustrine systems (Chafetz et al., 1991; Andrews et al., 1993, 1997; Zamarreño et al., 1997; Ordóñez et al., 2005; Arenas et al., 2007). The values fit a meteoric origin of the water and a variable influence of soilderived ${ }^{12} \mathrm{C}$ (Leng \& Marshall, 2004; Andrews, 2006). Moreover, the poor correlation coefficients between $\delta^{13} \mathrm{C}$ and $\delta^{18} \mathrm{O}$ may be related to deposition in hydrologically open systems (Talbot \& Kelts, 1990; Dunagan \& Turner, 2004; Leng \& Marshall, 2004; Cyr et al., 2005; VázquezUrbez et al., 2013), which fits the overall fluvial-lacustrine environment of the Upper Jurassic study area. In group 2, the moderate correlation value might be indicative of a longer residence time of the water.

The lower $\delta^{13} \mathrm{C}$ values of group 1 (section 4, La Fumarea; Fig. 13A) suggests a larger contribution of ${ }^{12} \mathrm{C}$ from soil organic matter to the water and calcite, probably from more abundant soil development relative to the areas represented by the other two groups of samples. However, the modern soil cover might have influenced low $\delta^{13} \mathrm{C}$ values; therefore, environmental interpretation based on this group should be cautious. Samples of group 2 show the lowest $\delta^{18} \mathrm{O}$

Table 2. Mean and range of stable-isotope values of the microbialite facies in the Vega Formation. Pearson correlation coefficient $(r)$ is also indicated. Groups refer to fields in Fig. 13A.

\begin{tabular}{|c|c|c|c|c|c|c|c|}
\hline & \multicolumn{3}{|c|}{$\delta^{13} \mathrm{C} \%$ V-PDB } & \multicolumn{3}{|c|}{$\delta^{18} \mathrm{O} \% \mathrm{~V}-\mathrm{PDB}$} & \multirow{2}{*}{$\begin{array}{l}\text { Correlation } \\
\text { coefficient }(r)\end{array}$} \\
\hline & Minimum & Maximum & Mean & Minimum & Maximum & Mean & \\
\hline All samples, $n=46$ & $-7 \cdot 86$ & $-5 \cdot 36$ & $-6 \cdot 34$ & $-6 \cdot 10$ & -3.95 & $-4 \cdot 82$ & $-0 \cdot 13$ \\
\hline Group 1 (JLF), $n=6$ & $-7 \cdot 86$ & $-7 \cdot 61$ & $-7 \cdot 79$ & $-5 \cdot 48$ & $-3 \cdot 97$ & $-4 \cdot 74$ & $-0 \cdot 19$ \\
\hline Group 2 (JAV-3, JLV-1), $n=6$ & $-6 \cdot 91$ & $-5 \cdot 36$ & $-5 \cdot 93$ & $-6 \cdot 10$ & $-5 \cdot 46$ & $-5 \cdot 73$ & $+0 \cdot 86$ \\
\hline Group 3 (rest of samples), $n=34$ & $-6 \cdot 82$ & $-5 \cdot 79$ & $-6 \cdot 16$ & $-5 \cdot 17$ & -3.95 & $-4 \cdot 69$ & -0.02 \\
\hline Light intervals, $n=17$ & $-7 \cdot 86$ & $-5 \cdot 98$ & $-6 \cdot 35$ & $-5 \cdot 95$ & $-3 \cdot 95$ & $-4 \cdot 87$ & $+0 \cdot 21$ \\
\hline Dark intervals, $n=19$ & $-7 \cdot 61$ & $-5 \cdot 36$ & $-6 \cdot 06$ & $-5 \cdot 60$ & $-4 \cdot 23$ & $-4 \cdot 76$ & $-0 \cdot 21$ \\
\hline
\end{tabular}


values, probably indicating a greater influence of ${ }^{16} \mathrm{O}$-enriched water, which suggests dominant inputs of isotopically less-evolved meteoric water (Andrews, 2006). This observation is in accordance with the common presence of siliceous extraclasts, which are related to erosion during higher discharge episodes as a result of increased precipitation. However, the moderate correlation between $\delta^{13} \mathrm{C}$ and $\delta^{18} \mathrm{O}$ of this group might reflect other fractionation processes (for example, the effects of evaporation). Given the small number of samples, this issue remains uncertain. In contrast, group 3 indicates that most studied sites had similar environmental conditions. The values suggest little to moderate change relative to the meteoric-water $\delta^{18} \mathrm{O}$ signature and moderate contributions of soil-derived ${ }^{12} \mathrm{C}$. This group reflects similar carbon isotopic processes and sources. Overall, the isotopic composition of group 3 is consistent with calcite precipitation in channels and mostly open (or short-term closed) ponded areas, including tufaceous palustrine areas, all of which were fed by meteoric, isotopically non-evolved water and supported riparian vegetation.

The cyclic variations of calcite $\delta^{18} \mathrm{O}$ values in the light and dark intervals (Fig. 13B) mostly reflect the dominant temperature-dependent fractionation effects (Hoefs, 1980) because evaporation should be negligible given the prevailing open character of the depositional system. According to the $\delta^{18} \mathrm{O}$ variations, most light, porous intervals and dark, dense intervals correspond to higher and lower water temperatures, respectively, as reported for $\delta^{18} \mathrm{O}$ values of laminated microbial deposits from other ancient and recent continental systems (Chafetz et al., 1991; Osácar et al., 2013). However, the reverse pattern is also present in certain studied samples.

An increase in water temperature of $1^{\circ} \mathrm{C}$ causes a decrease in the $\delta^{18} \mathrm{O}$ value of the associated calcite sediment of $\mathrm{ca} 0.24 \%$ (Craig, 1965). Based on this relationship, the difference in water temperature reflected by the dark and light intervals within each sampled oncoid ranges from 0.4 to $3 \cdot 7^{\circ} \mathrm{C}$, although most samples yield a range between $0.5^{\circ} \mathrm{C}$ and $2^{\circ} \mathrm{C}$. The mean temperature difference is $c a 0.6^{\circ} \mathrm{C}$ if the mean values of all dark and all light intervals are considered. Therefore, water temperature in the depositional environment of the carbonate fluvial-lacustrine system possibly experienced only small changes through time (seasonal and/or pluriannual changes). Nonetheless, the obtained values represent the minimum range of tempera- ture variation because, in addition to temperature, other processes (for example, variable intensity of mechanical $\mathrm{CO}_{2}$-removal or postsedimentary processes) may have contributed to the calcite oxygen isotope composition.

The parameters that may influence the sediment $\delta^{13} \mathrm{C}$ values are more diverse (Talbot \& Kelts, 1990; Leng \& Marshall, 2004). The pattern shown by most samples, with higher values for dark intervals and lower values for light intervals (Fig. 13C), may be related to changes in the precipitation volume through time (for example, rainy versus arid conditions). These changes can produce differences in: (i) the aquifer recharge, and thus the isotopic composition of the groundwater that feeds the streams; and (ii) the development of vegetation and the resulting soil-derived $\mathrm{CO}_{2}$ supply (Garnett et al., 2004; Andrews, 2006). Thus, the light intervals formed in more rainy conditions, in which the vegetation cover provided water with ${ }^{12} \mathrm{C}$-enriched $\mathrm{CO}_{2}$. In addition, the dissolved inorganic carbon (DIC) of groundwater feeding the streams was likely to be ${ }^{13} \mathrm{C}$-depleted due to the high recharge and short residence time of the water in the aquifer, relative to less rainy or drier conditions. In contrast, the dark intervals formed in less rainy conditions, with a lower supply of ${ }^{12} \mathrm{C}$-enriched $\mathrm{CO}_{2}$ from soils and the contribution of ${ }^{13} \mathrm{C}$-enriched DIC from the aquifer to the streams. The higher values of $\delta^{13} \mathrm{C}$ in recent stromatolites of the Ruidera Lakes Systems were interpreted to represent periods of drought, which featured lower quantities of organic carbon in the soils (Ordóñez et al., 2005). In the studied Jurassic case, the differences in $\delta^{13} \mathrm{C}$ values between the light and dark intervals for single oncoids are up to $1 \%$ (Fig. 13C), which might correspond, at least partially, to moderate seasonal and/or pluriannual variations in the precipitation volume.

Temperature can also influence the calcite $\delta^{13} \mathrm{C}$ composition through its effect on $\mathrm{CO}_{2}$-degassing in groundwater. Matsuoka et al. (2001) argued that the cyclic variation of $\delta^{13} \mathrm{C}$ values in present-day fluvial laminated tufa deposits in Japan was related to seasonal changes in the $\delta^{13} \mathrm{C}$ value of DIC in the groundwater, which was most likely to be caused by in-aquifer $\mathrm{CO}_{2}$ degassing. The degassing effect is stronger during winter, due to decreased subsurface air $\mathrm{pCO}_{2}$, which causes degassing of isotopically light $\mathrm{CO}_{2}$ from the groundwater, resulting in higher $\delta^{13} \mathrm{C}$ values for the remaining DIC in the groundwater fed-stream. The authors thus 
concluded that the positive covariation between $\delta^{13} \mathrm{C}$ and $\delta^{18} \mathrm{O}$ values was linked to temperature.

The effects of photosynthesis on the calcite isotopic composition through $\mathrm{CO}_{2}$ removal are not yet fully proven (Arp et al., 2001). The imprint of photosynthesis in fluvial tufa deposits is likely to be small, except perhaps in arid systems (Andrews \& Brasier, 2005; Andrews, 2006).

Therefore, the cyclic and parallel variation of $\delta^{13} \mathrm{C}$ and $\delta^{18} \mathrm{O}$ values in most light and dark intervals (Fig. 13B and C) in the studied Jurassic samples might be explained, at least partially, by changes in water temperature and precipitation volume. These changes might correspond to seasonal and/or pluriannual variations.

\section{DISCUSSION - PALAEOGEOGRAPHIC CONTEXT - CLIMATE, HYDROLOGY AND TECTONICS}

The most noticeable features of the studied carbonate deposits are their occurrence within a fluvial siliciclastic succession and their close association with normal faults. The extensional tectonic regime that affected the region during the Late Jurassic caused the uplift and emergence of a large part of the territory. The siliciclastic deposits of the Vega Formation represent the middle and distal parts of an east/north-eastward flowing siliciclastic fluvial system that was sourced from Proterozoic and Lower Palaeozoic rocks (García-Ramos, 1997). Close to the studied sites, the presence of faults with general northwest/south-east and east-west orientations (Fig. 1B) that operated as normal faults in the Late Jurassic (Uzqueda et al., 2013) controlled the presence of uplifted areas of Triassic-Middle Jurassic rocks and favoured: (i) springs of water rich in $\mathrm{HCO}_{3}{ }^{-}$and $\mathrm{Ca}^{++}$from the uppermost Triassic-Lower Jurassic (Hettangian-Sinemurian) rock aquifer, delivered to otherwise dry lands; and (ii) the occurrence of fluvial, palustrine and lacustrine carbonate deposition in areas partially isolated (elevated) from the adjacent siliciclastic fluvial system (Fig. 12). Subsidence induced by fault activity also controlled the thickness distribution through space (Platt, 1995), with thicker carbonate deposits located in the south-western, siliciclastic-starved sector closer to the carbonate sources (sector 3), and thicker siliciclastic deposits located towards the north-eastern sector (sector 2). Accordingly, the distal areas of the carbonate system could be influenced more by progradation or lateral migration processes of the siliciclastic fluvial system.

To the south-east of the studied area ( $c a$ $100 \mathrm{~km}$ ), Hernández et al. (1998) also proposed a fault-controlled context to explain the development of microbial carbonate deposits close to a north-west/south-east normal fault during the Kimmeridgian-Berriasian. These deposits, referred to as travertines, formed in streams fed by springs arising from the fault-controlled relief and were associated with lacustrine areas. Moreover, the activity of such fault determined the origin and sedimentary evolution of the basin.

The studied carbonate deposits of the Vega Formation crop out over areas that are more than $50 \mathrm{~km}$ apart. In many current tufa-precipitating streams, the locus at which calcite deposition commences is often located well downstream from the springs, as far as required for $\mathrm{CO}_{2}$ outgassing to cause the calcite saturation index to rise to positive values (e.g. Herman \& Lorah, 1988; Liu et al., 1995; Kawai et al., 2006; Arp et al., 2010; Auqué et al., 2013; Arenas et al., 2014). This fact supports the hypothesis that the Late Jurassic springs could have been located at some distance from the outcropping carbonate deposits. The carbonate intercalations within the siliciclastic system reflect the variable extent/development of a single carbonate fluvial-lacustrine system and coexisting small alluvial fans through time.

In the Late Jurassic, Iberia was an isolated landmass in the dry (semi-arid) zone. Palaeolatitude estimates for Iberia range from $\mathrm{Ca} 30^{\circ}$ north (Smith et al., 1994; Golonka et al., 1996) to $30^{\circ}$ to $40^{\circ}$ north (Stampfli \& Borel, 2002) or even lower (ca $25^{\circ}$ north; Thierry, 2000; Osete et al., 2011). Platt (1995) suggested a semi-arid environment for Upper Jurassic alluvial fans and paleosols in the western Cameros Basin (northern Spain). According to Myers et al. (2012) the Late Jurassic palaeoclimate of Portugal was warm and sub-humid with a strongly seasonal pattern of precipitation. These authors provided maximum estimates of soil temperature derived from isotopic analysis of clay minerals in palaeosols between $27^{\circ} \mathrm{C}$ and $34^{\circ} \mathrm{C}$ (surface temperatures) and a mean annual precipitation estimate of $c a 1100 \mathrm{~mm} \mathrm{yr}^{-1}$. Although seasonal precipitation and moisture deficits were indicated by the palaeosols, a coastal marine climate regime was proposed by those authors to explain more rainfall in Portugal than in other interior areas of similar latitude (for example, the Morrison Formation in the western USA). Demko et al. 
(2004), based on calcareous palaeosol analysis, and Parrish et al. (2004), based on botanical studies, also concluded that the deposition of the Upper Jurassic Morrison Formation occurred in a semi-arid climate. Moreover, Dunagan \& Turner (2004) provided sedimentological, palaeontological and stable-isotope data that supported semi-arid conditions during deposition in open carbonate lakes and wetlands of the Morrison Formation. More recent multiproxy studies provided evidence of highly variable palaeoprecipitation in the Morrison Formation, and suggested that the mean annual precipitation estimates from the Vega Formation are closer to those of the arid continental-interior environments of the Morrison Formation (Myers et al., 2014).

Studies of different lacustrine and fluvial deposits around the world support general semiarid conditions during the Late Jurassic, even in higher latitude areas (Rees et al., 2004). The lower Purbeck limestones on the Dorset coast (UK) contain soils that are interpreted to have formed in a seasonally arid (Mediterranean-type) climate setting (Francis, 1984). More recently, Bosence (2012) argued that the environment in which the lower Purbeck limestones formed on the Isle of Portland varied laterally from a hypersaline to brackish and possibly freshwater lacustrine system; in this system, the conifer trees and soils indicate a seasonal, semi-arid climate. The sedimentary features of the Puesto Almada Member (southern Argentina) are in accordance with an arid climatic scenario throughout the Late Jurassic and record strong seasonality, with periods of higher humidity represented by wetlands and lacustrine sediments (Cabaleri et al., 2013).

The climate during deposition of the Vega Formation conforms to semi-arid conditions, as indicated by the local presence of gypsum (interstitial deposits), the palynological composition and the attributes of extensive palaeosols in the fine-grained floodplain deposits of the siliciclastic system. The studies of pollen and spores in different deposits of the Vega Formation indicate the dominance of coastal gymnosperms and ferns adapted to dryness and suggest a subtropical climate, mostly warm and arid, with occasional occurrence of slightly more humid conditions (Barrón et al., 2008; Barrón, 2010). Based on the palaeosol types and their features, Gutierrez \& Sheldon (2012) suggested that short-stature, shrubby vegetation inhabited those flood plains. Those authors estimated mean annual precipitation values of 400 to $980 \mathrm{~mm} \mathrm{yr}^{-1}$ and mean annual temperature values of 8 to $15^{\circ} \mathrm{C}$, and proposed a strongly seasonal precipitation regime in Asturias during the Late Jurassic.

The sedimentological features of the studied carbonate-lacustrine deposits in the Vega Formation (i.e. frequent erosion linked to channel overflowing and rapid lateral changes of the different subenvironments) are in accordance with a semi-arid climatic scenario, in which the changes in water discharge were associated with strong seasonal and/or pluriannual variations in precipitation. The cyclic pattern of $\delta^{13} \mathrm{C}$ values of the light and dark intervals in oncoids probably reflects changes in precipitation through variations in the aquifer recharge and vegetation development (for example, as described by Matsuoka et al., 2001 and Andrews, 2006). Moreover, the discontinuous growth of the microbial lamination and the asymmetrical thicknesses in certain oncoids also attest to variable hydrological conditions. It should be noted that the La Fumarea area (section 4) might correspond to a context with more vegetation and/or soils, based on the lower $\delta^{13} \mathrm{C}$ values of the oncoids, perhaps an area of higher elevation with greater water supply. Although the available $\delta^{13} \mathrm{C}$ data are inconclusive, the sedimentological data suggests that this area was a relatively siliciclastic-starved, perhaps partially isolated, setting in sector 3 , bounded by Jurassic relief associated with dominantly north-west/southeast oriented faults, from which a greater water supply may have been provided during wetter periods.

Regarding temperature, the mean annual air temperature values of 8 to $15^{\circ} \mathrm{C}$ proposed by Gutierrez \& Sheldon (2012) seem more reasonable for the studied area than the much higher values estimated by Myers et al. (2012) in Portugal. Regardless, seasonal variations in air temperature are expected to have been mild given the latitudinal position of the study area. The cyclic $\delta^{18} \mathrm{O}$ pattern in the light and dark intervals in the oncoids reflects slight seasonal and/ or pluriannual changes in the water temperature of the carbonate system. Nonetheless, the expected mostly constant water temperature of springs feeding the system through the year might have decreased the influence of air temperature on the streams and ponds. However, the estimated water temperature ranges should be regarded as minima, given that other factors may have influenced the isotopic composition. 
In any case, the carbonate facies of the Vega Formation are typical of the ambient-temperature fluvial environment, and there is no sedimentological or isotopic evidence of hot-spring influence.

Environmental changes through time are difficult to envisage, given the lack of precise correlation among the different studied sites in this work. Moreover, the available data from the present outcrops do not allow for the assessment of the influence of fault activity on the evolution of the alluvial fans or progradation stages of the carbonate fluvial-lacustrine system (for example, through changes in slope). The results of this study suggest that the variable development (i.e. extent) of the carbonate fluvial-lacustrine system through time was possibly controlled by climate (through changes in the precipitation). Within the general semi-arid context in Late Jurassic times, the greatest development of the carbonate fluvial-lacustrine system might have occurred during periods of slightly wetter conditions. This phenomenon is compatible with the isotopic and sedimentological attributes of the carbonate fluvial-lacustrine system that were impacted by short-term climate changes consistent with a general semi-arid climate.

\section{CONCLUSIONS}

The Vega Formation carbonate deposits formed in a low-gradient fluvial-lacustrine system with shallow channels and ponds in a marshy area. The microbialite $\delta^{13} \mathrm{C}$ and $\delta^{18} \mathrm{O}$ values and their poor correlation are consistent with deposition in a hydrologically open system fed by ambienttemperature meteoric water and with riparian vegetation.

The carbonate fluvial-lacustrine system was supplied by water sourced from a Rhaetian to Sinemurian rock aquifer in an otherwise dry area. Normal faults that were active during deposition of the Vega Formation created the scenario that favoured: (i) $\mathrm{HCO}_{3}{ }^{-}$-rich and $\mathrm{Ca}^{++}$rich springs from the carbonate rock aquifer; and (ii) the occurrence of fluvial, palustrine and lacustrine carbonate deposition in areas partially isolated (elevated) from the adjacent siliciclastic fluvial system. Fault-induced subsidence controlled the thicknesses of the carbonates in the siliciclastic-starved areas close to the Jurassic rock relief.

Seven carbonate facies have been characterized. Stromatolites and oncoid rudstones formed in channels and shallow ponds. Oncoid-intraclast rudstones and packstones formed as a result of high-discharge episodes associated with channel overflow and extensive erosion; this affected the deposits of the concurrent siliciclastic system. Facies containing charophytes, ostracods and freshwater bivalves (oncoid-bioclast-intraclast rudstones, packstones and wackestones and intraclast-bioclast wackestones) developed in intrachannel and interchannel ponds that were affected by channel overflow. Marlstones and marly limestones were deposited as a result of stream input that led to the level rise of small lakes. In addition, clast-supported polygenic calcareous conglomerates represent deposition of small alluvial fans that were sourced from uplifted Lower and Middle Jurassic rocks, and that reached the carbonate fluvial-lacustrine system during higher discharge episodes.

The three types of lamination in stromatolites and oncoids reflect distinct morphological types of the cyanobacterial communities. Composite lamination probably represents seasonal to pluriannual deposition. The textural pattern of lamination shows covariant $\delta^{13} \mathrm{C}$ and $\delta^{18} \mathrm{O}$ variations, most probably linked to seasonal and/or pluriannual cycles of changing precipitation and temperature.

The sedimentological features of the carbonate fluvial-lacustrine system indicate frequent erosion by channel overflowing and rapid lateral variations in the different subenvironments. The cyclic $\delta^{13} \mathrm{C}$ pattern of light and dark intervals in oncoids and the discontinuous or asymmetrical growth of certain oncoids attest to short-term variations in the precipitation regime. These observations support a variable hydrology linked to a moderately to strongly contrasted seasonal and/or pluriannual precipitation regime, consistent with the semi-arid conditions during the Late Jurassic in the studied palaeolatitudinal zone. The maximum development of the carbonate system could have been related to periods of slightly wetter conditions.

The results reveal the influence of short-term climate cycles on the isotopic and sedimentological attributes of carbonate fluvial-lacustrine deposits, whose occurrence in a semi-arid context is associated with water springs in partially isolated areas related to normal-fault activity. Therefore, the studied system represents an example of the combined influence of climate and tectonics which provides new insights into interpreting the occurrence of carbonate 
deposition in siliciclastic fluvial systems of fault-controlled basins.

\section{ACKNOWLEDGEMENTS}

This research was financed by projects CG200909216BTE and CGL2012-33281 (Spanish Government and European Regional Development Fund). It forms part of the activities of the Research Group Continental Sedimentary Basin Analysis (Government of Aragón-University of Zaragoza). Dr. Pardo is thanked for his wise advice. We are also grateful to the reviewers and editors, whose comments improved the manuscript substantially.

\section{REFERENCES}

Alonso, J.L., Gallastegui, J., García-Ramos, J.C. and Poblet, J. (2009) Estructuras mesozoicas y cenozoicas relacionadas con la apertura y cierre parcial del Golfo de Vizcaya (Zona Cantábrica-Asturias). 6th Symposium on the Atlantic Iberian Margin, Guia de campo, Oviedo, $18 \mathrm{pp}$.

Andersen, D.T., Sumner, D.Y., Hawes, I., Webster-Brown, J. and McKay, P.C. (2011) Discovery of large conical stomatolites in Lake Untersee, Antarctica. Geobiology, 9, 280-293.

Andrews, J.E. (2006) Palaeoclimatic records from stable isotopes in riverine tufas: synthesis and review. Earth-Sci. Rev., 75, 85-104.

Andrews, J.E. and Brasier, A.T. (2005) Seasonal records of climate change in annually laminated tufas: short review and future prospects. J. Quatern. Sci., 20, 411-421.

Andrews, J.E., Riding, R. and Dennis, P.F. (1993) Stable isotopic compositions of Recent freshwater cyanobacterial carbonates from the British Isles: local and regional environmental controls. Sedimentology, 40, 303-314.

Andrews, J.E., Riding, R. and Dennis, P.F. (1997) The stable isotope record of environmental and climatic signals in modern terrestrial microbial carbonates from Europe. Palaeogeogr. Palaeoclimatol. Palaeoecol., 129, 171-189.

Aramburu, C. and Bastida, F. (Eds) (1995) Geología de Asturias. Ediciones Trea, Gijón, 314 pp.

Arenas, C., Gutiérrez, F., Osácar, C. and Sancho, C. (2000) Sedimentology and geochemistry of fluvial-lacustrine tufa deposits controlled by evaporite solution subsidence in the central Ebro Depresión, NE Spain. Sedimentology, 47, 883-909.

Arenas, C., Cabrera, L. and Ramos, E. (2007) Sedimentology of tufa facies and continental microbialites from the Palaeogene of Mallorca Island (Spain). Sed. Geol., 197, 1-27.

Arenas, C., Vázquez-Urbez, M., Auqué, L., Sancho, C., Osácar, C. and Pardo, G. (2014) Intrinsic and extrinsic controls of spatial and temporal variations in modern fluvial tufa sedimentation: a thirteen-year record from a semi-arid environment. Sedimentology, 61, 90-132.

Arenas-Abad, C., Vázquez-Urbez, M., Pardo-Tirapu, G. and Sancho-Marcén, C. (2010) Fluvial and associated carbonate deposits. In: Carbonates in Continental Settings:
Facies, Environments and Processes (Eds A.M. AlonsoZarza and L.H. Tanner), Dev. Sedimentol., 61, 133-175.

Arp, G., Wedemeyer, N. and Reitner, J. (2001) Fluvial tufa formation in a hard-water creek (Deinschwanger Bach, Franconian Alb, Germany). Facies, 44, 1-22.

Arp, G., Bissett, A., Brinkmann, N., Cousin, S., deBeer, D., Friedl, T., Mohr, K.I., Neu, T.R., Reimer, A., Shiraishi, F., Stackebrandt, E. and Zippel, B. (2010) Tufa-forming biofilms of German karstwater streams: microorganisms, exopolymers, hydrochemistry and calcification. In: Tufas and Speleothems: Unravelling the Microbial and Physical Controls (Eds H.M. Pedley and M. Rogerson), Geol. Soc. Spec. Publ., 336, 83-118.

Astibia, H., López-Martínez, N., Elorza, J. and Vicens, E. (2012) Increasing size and abundance of microbialites (oncoids) in connection with the K/T boundary in nonmarine environments in the South Central Pyrenees. Geol. Acta, 10, 209-226.

Auqué, L., Arenas, C., Osácar, C., Pardo, G., Sancho, C. and Vázquez-Urbez, M. (2013) Tufa sedimentation in changing hydrological conditions: the River Mesa (Spain). Geol. Acta, 11, 85-102.

Bádenas, B., Aurell, M., Armendáriz, M., Rosales, I., GarcíaRamos, J.C., González, B. and Piñuela, L. (2012) Sedimentary and chemostratigraphic record of climatic cycles in Lower Pliensbachian marl-limestone platform successions of Asturias (North Spain). Sed. Geol., 281, 119-138.

Barrón, E. (2010) Las series fluviales del Jurásico superior (Formación Vega). Palinología. In: V Congreso del Jurásico de España, Guía de campo, excursión A (Ed. J.C. GarcíaRamos), pp. 64-68. Museo del Jurásico de Asturias, Colunga.

Barrón, E., García-Ramos, J.C., Piñuela, L. and RuizOmeñaca, J.I. (2008) Aspectos palinológicos de la Formación Vega (Ribadesella). Jurásico Superior de Asturias. In: XXIV Jornadas de la Sociedad Española de Paleontología, Abstracts (Eds J.I. Ruiz-Omeñaca, L. Piñuela and J.C. García-Ramos), pp. 259-260. Museo del Jurásico de Asturias, Colunga.

Bosence, D. (2012) Mesozoic, syn-rift, non-marine, microbialites from the Wessex Basin, UK. In: Microbial Carbonate Reservoir Characterization, AAPG Hedberg Conference, Houston, TX. AAPG Search and Discovery, Article 90153, 3 pp.

Cabaleri, N.G., Benavente, C.A., Monferran, M.D., Narváez, P.L., Volkheimer, W., Gallego, O.F. and Do Campo, M.D. (2013) Sedimentology and palaeontology of the Upper Jurassic Puesto Almada Member (Cañadón Asfalto Formation, Fossati sub-basin), Patagonia Argentina: Palaeoenvironmental and climatic significance. Sed. Geol., 296, 103-121.

Casanova, J. (1994) Stromatolites from the East African Rift: a synopsis. In: Phanerozoic Stromatolites II (Eds J. Bertrand-Sarfati and C. Monty), pp. 193-226. Kluwer Academic Publishers, Dordrecht, The Netherlands.

Caudwell, C., Lang, J. and Pascal, A. (2001) Lamination of swampy-rivulets Rivularia haematites stromatolites in a temperate climate. Sed. Geol., 143, 125-147.

Chafetz, H.S., Utech, N.M. and Fitzmaurice, S.P. (1991) Differences in the d18O and d13C signatures of seasonal laminae comprising travertine stromatolites. J. Sed. Petrol., 61, 1015-1028.

Ciry, R. (1940) Étude géologique d'une partie des provincies de Burgos, Palencia, León et Santander. Bull. Soc. Hist. Nat. Toulouse, 74, 519 pp. 
Craig, H. (1965) The measurement of oxygen isotope palaeotemperatures. In: Stable Isotopes in Oceanographic Studies and Palaeotemperatures (Ed. E. Tongiorgi), pp. 161-182. Consiglio Nazionale Della Richerche, Laboratorio de Geologia Nucleare, Pisa.

Cyr, A.J., Currie, B.S. and Rowley, D.B. (2005) Geochemical evaluation of Fenghuoshan Group lacustrine carbonates, north-central Tibet: implications for the paleoaltimetry of the Eocene Tibetan Plateau. J. Geol., 113, 517-533.

Delvene, G., Lozano, R., Munt, M., Piñuela, L and GarcíaRamos, J.C. (2013) Unionoids (Bivalvia) and their associated microbialites from the Late Jurassic of Asturias (Spain). In: XXIX Jornadas de Paleontología, Libro de resúmenes (Eds C. Álvarez-Vázquez and I. López Rodríguez), pp. 147-148. Real Jardín Botánico de Córdoba, Córdoba (España).

Demko, T.M., Currie, B.S. and Nicoll, K.A. (2004) Regional paleoclimatic and stratigraphic implications of paleosols and fluvial/overbank architecture in the Morrison Formation (Upper Jurassic), Western Interior, USA. Sed. Geol., 167, 115-135.

Diéguez, C., Hernández, J.M. and Pujalte, V. (2009) A fernbennettitalean floral assemblage in Tithonian-Berriasian travertine deposits (Aguilar Formation, Burgos-Palencia, N Spain) and its palaeoclimatic and vegetational implications. J. Iber. Geol., 35, 127-140.

Drysdale, R.N. and Gillieson, D. (1997) Micro-erosion meter measurements of travertine deposition rates: a case study from Louie Creek, northwest Queensland, Australia. Earth Surf. Proc. Land., 22, 1037-1051.

Dunagan, S.P. and Turner, C.R. (2004) Regional paleohydrologic and paleoclimatic settings of wetland/ lacustrine depositional systems in the Morrison Formation (Upper Jurassic), Western Interior, USA. Sed. Geol., 167, 269-296.

Evans, J.E. (1999) Recognition and implications of Eocene tufas and travertines in the Chaldron Formation, White River Group, Badland of South Dakota. Sedimentology, 46, 771-789.

Francis, J.E. (1984) The seasonal environment of the Purbeck (Upper Jurassic) fossil forests. Palaeogeogr. Palaeoclimatol. Palaeoecol., 48, 285-307.

Freytet, P. and Plaziat, J.C. (1982) Continental Carbonate Sedimentation and Pedogenesis. Late Cretaceous and Early Tertiary of Southern France. Contributions to Sedimentology, Vol. 12. E. Schweizerbart'sche Verlag, Stuttgart, $213 \mathrm{pp}$.

Freytet, P. and Verrecchia, E. (1998) Freshwater organisms that build stromatolites: a synopsis of biocrystallization by prokaryotic and eukaryotic algae. Sedimentology, 45, 535563.

Fürsich, F.T., Werner, W., Delvene, G., García-Ramos, J.C., Bermúdez-Rochas, D.D. and Piñuela, L. (2012) Taphonomy and palaeoecology of high-stress benthic associations from the Upper Jurassic of Asturias, northern Spain. Palaeogeogr. Palaeoclimatol. Palaeoecol., 358-360, $1-18$.

García-Ramos, J.C. (1997) La sucesión Jurásica de la cuenca Asturiana: Entorno paleogeográfico regional y relaciones Tectónica-Sedimentación. In: IV Congreso del Jurásico de España, pp. 13-14. Alcañiz, Teruel.

García-Ramos, J.C., Piñuela, L. and Lires, J. (2006) Atlas del Jurásico de Asturias. Ediciones Nóbel, Oviedo (España), 225 pp.
García-Ramos, J.C., Aramburu, C. and Piñuela, L. (2010a) Las series fluviales del Jurásico superior (Formación Vega). Descripción de la serie y ambientes sedimentarios. In: $V$ Congreso del Jurásico de España, Guía de campo, Excursión A (Ed. J.C. García-Ramos), pp. 56-63. Museo del Jurásico de Asturias, Colunga.

García-Ramos, J.C., Piñuela, L., Uzkeda, H., Poblet, J., Bulnes, M., Alonso, J.L. and Suárez Vega, L.C. (2010b) Travertinos ricos en oncoides asociados a paleomanantiales y lagos efímeros próximos a fallas sinsedimentarias en el Jurásico Superior de Asturias. In: Comunicaciones del $V$ Congreso del Jurásico deEspaña (Eds J.I. Ruiz-Omeñaca, L. Piñuela and J.C. García-Ramos), pp. 83-91. Museo del Jurásico de Asturias, Colunga.

García-Ramos, J.C., Piñuela, L. and Rodríguez-Tovar, F.J. (2011) Introduction to the Jurassic of Asturias. In: Postworkshop Field Trip Guide. XI International Ichnofabric Workshop, pp. 3-8. Museo del Jurásico de Asturias, Colunga.

Garnett, E.R., Andrews, J.E., Preece, R.C. and Dennis, P.F. (2004) Climatic change recorded by stable isotopes and trace elements in a British Holocene tufa. J. Quatern. Sci., 19, 251-262.

Gierlowski-Kordesch, E.H. (1998) Carbonate deposition in an ephemeral siliciclastic alluvial system: Jurassic Shuttle Meadow Formation, Newark Supergroup, Hartford Basin, USA. Palaeogeogr. Palaeoclimatolol. Palaeoecol., 140, 161-184.

Gierlowski-Kordesch, E.H., Finkelstein, D.B., Truchan, J.J. and Kallini, K.D. (2013) Carbonate lakes associated with distal siliciclastic perennial-river systems. J. Sed. Res., 83, 1114-1129.

Golonka, J., Edrich, M.E., Ford, D.W., Pauken, R.J., Bocharova, N.Y. and Scotese, C.R. (1996) Jurassic paleogeographic maps of the world. In: The Continental Jurassic (Ed. M. Morales), pp. 1-5. Museum of Northern Arizona, Flagstaff.

Golubic, S. (1991) Modern stromatolites-a review. In: Calcareous Algae and Stromatolites (Ed. R. Riding), pp. 541-561. Springer-Verlag, Berlin.

Golubic, S., Violante, C., Plenković-Moraj, A. and Grgasović, T. (2008) Travertines and calcareous tufa deposits: an insight into diagenesis. Geol. Croat., 61, 363-378.

Gradziński, M. (2010) Factors controlling growth of modern tufa: results of a field experiment. In: Tufas and Speleothems: Unravelling the Microbial and Physical Controls (Eds M. Pedley and M. Rogerson), Geol. Soc. Spec. Publ., 336, 143-191.

Gutierrez, K. and Sheldon, N.D. (2012) Paleoenvironmental reconstruction of Jurassic dinosaur habitats of the Vega Formation, Asturias, Spain. GSA Bull., 124, 596610.

Hägele, D., Leinfelder, R., Grau, J., Burmeister, E.-G. and Struck, U. (2006) Oncoids from the river Alz (southern Germany): tiny ecosystems in a phosphorus-limited environment. Palaeogeogr. Palaeoclimatolol. Palaeoecol., 237, 378-395.

Herman, J.S. and Lorah, M.M. (1988) Calcite precipitation rates in the field: measurement and prediction for a travertine-depositing stream. Geochim. Cosmochim. Acta, 52, 2347-2355.

Hernández Gómez, J.M. (2000) Sedimentología, paleogeografía y relaciones tecónica/sedimentación de los sistemas fluviales, aluviales y palustres de la cuenca rift de Aguilar (Grupo Campóo, Jurásico superior-Cretácico 
inferior de Palencia, Burgos y Cantabria). PhD Thesis, Departamento de Estratigrafía y Paleontología, Facultad de Ciencias, Universidad del País Vasco, 324 pp. (unpubl).

Hernández, J.M., Diéguez, C., Pujalte, V., Robles, S. and Wright, V.P. (1998) Reconocimiento de acumulaciones travertínicas fósiles en la Fm. Aguilar (KimmeridgienseBerriasiense de Palencia y Burgos): implicaciones paleoecológicas y paleohidrológicas. Geogaceta, 24, 167170.

Hoefs, J. (1980) Stable Isotope Geochemistry, 6th edn. Springer, Berlin, 285 pp.

Kawai, T., Kano, A., Matsuoka, J. and Ihara, T. (2006) Seasonal variation in water chemistry and depositional processes in a tufa-bearing stream in SW-Japan, based on 5 years of monthly observations. Chem. Geol., 232, 33-53.

Kumar, R., Suresh, N., Sangode, S.J. and Kumaravel, V. (2007) Evolution of the Quaternary alluvial fan system in the Himalayan foreland basin: implications for tectonic and climatic decoupling. Quatern. Int., 159, 6-20.

Leinfelder, R.R. (1985) Cyanophyte calcification morphotypes and depositional environments (Alenquer Oncolite Upper Kimmeridgian? Portugal). Facies, 12, 253-274.

Leinfelder, R.R. and Hartkopf-Fröder, C. (1990) In situ accretion mechanism of convavo-convex lacustrine oncoids ("swallow nests") from the Oligocene of the Mainz Basin, Rhineland, FRG. Sedimentology, 37, 287-301.

Leng, M.J. and Marshall, J.D. (2004) Palaeoclimate interpretation of stable isotope data from lake sediment archives. Quatern. Sci. Rev., 23, 811-831.

Lepvrier, C. and Martínez García, E. (1990) Fault development and stress evolution of the post-Hercynian Asturian Basin (Asturias and Cantabria, northwestern Spain). Tectonophysics, 184, 345-356.

Liu, Z., Svensson, U., Dreybrodt, W., Yuan, D. and Buhmann, D. (1995) Hydrodynamic control of inorganic calcite precipitation in Huanglong Ravine, China: field measurement and theoretical prediction of deposition rates. Geochim. Cosmochim. Acta, 59, 3087-3097.

López-Gómez, J. and Arche, A. (1997) The Upper Permian Boniches Conglomerates Formation: evolution from alluvial fan to fluvial system environments and accompanying tectonic and climatic controls in the southeast Iberian Ranges, central Spain. Sed. Geol., 114, 267-294.

Manzo, E., Perri, E. and Tucker, M.E. (2012) Carbonate deposition in a fluvial tufa system: processes and products (Corvino Valley - southern Italy). Sedimentology, 59, 553577.

Matsuoka, J., Kano, A., Oba, T., Watanabe, T., Sakai, S. and Seto, K. (2001) Seasonal variation of stable isotopic compositions recorded in a laminated tufa, SW Japan. Earth Planet. Sci. Lett., 192, 31-44.

McCrea, J.M. (1950) On the isotope chemistry of carbonate and a paleotemperature scale. J. Chem. Phys., 18, 587-849.

Meléndez, N. and Gómez-Fernández, J.C. (2000) Continental deposits of the Eastern Cameros Basin (Northern Spain) during Tithonian-Berriasian time. In: Lake Basins Through Space and Time (Eds E.H. Gierlowski-Kordesch and K.R. Kelts), AAPG Stud. Geol., 46, 263-278.

Merz-Preiß, M. and Riding, R. (1999) Cyanobacterial tufa calcification in two freshwater streams: ambient environment, chemical thresholds and biological processes. Sed. Geol., 126, 103-124.

Miall, A.D. (1996) The Geology of Fluvial Deposits. Springer, Berlin, 582 pp.
Monty, C.L.V. (1976) The origin and development of cryptalgal fabrics. In: Stromatolites (Ed. M.R. Walter), Dev. Sedimentol., 20, 193-249.

Myers, T., Tabor, N.J., Jacobs, L.L. and Mateus, O. (2012) Palaeoclimate of the Late Jurassic of Portugal: comparison with the Western United States. Sedimentology, 59, 16951717.

Myers, T., Tabor, N.J. and Rosenau, N.A. (2014) Multiproxy approach reveals evidence of highly variable paleoprecipitation in the Upper Jurassic Morrison Formation (western United States). GSA Bull., 126, 11051116.

Noffke, N. and Awramik, S.M. (2013) Stromatolites and MISS-differences between relatives. GSA Today, 23, 4-9.

Ordóñez, S. and García del Cura, M.A. (1983) Recent and Tertiary fluvial carbonates in central Spain. In: Ancient and Modern Fluvial Systems (Eds J.D. Collinson and J. Lewin), IAS Spec. Publ., 6, 485-497.

Ordónez, S., Carballal, R. and García del Cura, A. (1980) Carbonatos biogénicos actuales en la cuenca del río Dulce (provincia de Guadalajara). Bol. Real. Soc. Esp. Hist. Nat. (Geol.), 78, 303-315.

Ordóñez, S., González Martín, J.A., García del Cura, M.A. and Pedley, H.M. (2005) Temperate and semi-arid tufas in the Pleistocene to recent fluvial barrage system in the Mediterranean area: the Ruidera Lakes Natural Park (central Spain). Geomorphology, 69, 332-350.

Osácar, M.C., Arenas, C., Vázquez-Urbez, M., Sancho, C., Auqué, L.F. and Pardo, G. (2013) Environmental factors controlling the $\delta^{13} \mathrm{C}$ and $\delta^{18} \mathrm{O}$ variations of recent fluvial tufas: a 12-year record from the Monasterio de Piedra Natural Park (NE Iberian Peninsula). J. Sed. Res., 83, 309322.

Osete, M.L., Gómez, J.J., Pavón-Carrasco, F.J., Villalaín, J.J., Palencia-Ortas, A., Ruiz-Martínez, V.C. and Heller, F. (2011) The evolution of Iberia during the Jurassic from palaeomagnetic data. Tectonophysics, 502, 105-120.

Parcerisa, D., Gómez-Gras, D. and Martín-Martín, J.D. (2006) Calcretes, oncolites, and lacustrine limestones in Upper Oligocene alluvial fans of the Montgat area (Catalan Coastal Ranges, Spain). In: Paleoenvironmental Record and Applications of Calcretes and Palustrine Carbonates (Eds A.M. Alonso-Zarza and L.H. Tanner), Geol. Soc. Am. Spec. Pap., 416, 105-118.

Park, R.K. (1976) A note on the significance of lamination in stromatolites. Sedimentology, 23, 379-393.

Parrish, J.T., Peterson, F. and Turner, C.E. (2004) Jurassic "savannah"-plant taphonomy and climate of the Morrison Formation (Upper Jurassic, Western USA). Sed. Geol., 167, 137-162.

Pedley, H.M. (2009) Tufas and travertines of the Mediterranean region: a testing ground for freshwater carbonate concepts and developments. Sedimentology, 56, 221-246.

Pentecost, A. and Franke, U. (2010) Photosynthesis and calcification of the stromatolitic freshwater cyanobacterium Rivularia. Eur. J. Phycol., 45, 345-353.

Perry, C.T. (1994) Freshwater tufa stromatolites in the basal Purbeck Formation (Upper Jurassic), Isle of Portland, Dorset. Geol. J., 29, 119-135.

Petryshyn, V.A., Corsetti, F.A., Berelson, W.M., Beaumont, W. and Lund, S.P. (2012) Stromatolite lamination frequency, Walker Lake, Nevada: implications for stromatolites as biosignatures. Geology, 40, 499-502.

Pla-Pueyo, S., Gierlowski-Kordesch, E.H., Viseras, C. and Soria, J.M. (2009) Major controls on sedimentation during 
the evolution of a continental basin: Pliocene-Pleistocene of the Guadix Basin (Betic Cordillera, southern Spain). Sed. Geol., 219, 97-114.

Platt, N.H. (1989) Lacustrine carbonates and pedogenesis: sedimentology and origin of palustrine deposits from the Early Cretaceous Rupelo Formation, W Cameros Basin, N Spain. Sedimentology, 36, 665-684.

Platt, N.H. (1995) Sedimentation and tectonics of a synrift succession: Upper Jurassic alluvial fans and palaeokarst at the Cimmenian unconformity, western Cameros Basin, northern Spain. Spec. Publs. Int. Ass. Sediment., 22, 219236.

Pujalte, V., Robles, S. and Hernández, J.M. (1996) La sedimentación continental del Grupo Campóo (MalmCretácico basal de Cantabria, Burgos y Palencia): testimonio de un reajuste hidrográfico al inicio de una fase rift. Cuad. Geol. Ibérica, 21, 227-251.

Ramírez del Pozo, J. (1969) Bioestratigrafía y Paleogeografía del Jurásico de la costa asturiana (zona de Oviedo-GijónVillaviciosa). Bol. Geol. Min., 80, 307-332.

Rat, P. (1962) Contribution à l'etude stratigraphique du Purbeckien-Wealdien de la region de Santander. Bull. Soc. Géol. France, 4, 3-12.

Rees, P.M., Noto, C.R., Parrish, J.M. and Parrish, J.T. (2004) Late Jurassic climates, vegetation, and dinosaur distributions. J. Geol., 112, 643-653.

Riding, R. (2000) Microbial carbonates: the geological record of calcified bacterial-algal mats and biofilms. Sedimentology, 47, 179-214.

Seong-Joo, L., Browne, K.M. and Golubic, S. (2000) On stromatolite lamination. In: Microbial Sediments (Eds R. Riding and S.M. Awramik), pp. 16-24. Springer-Verlag, Berlin.

Shapiro, R.S., Fricke, H.C. and Fox, K. (2009) Dinosaurbearing oncoids from ephemeral lakes of the Lower Cretaceous Cedar Mountain Formation, Utah. Palaios, 24, 51-58.

Smith, A.G., Smith, D.G. and Funnell, B.M. (1994) Atlas of Mesozoic and Cenozoic Coastlines. Cambridge University Press, Cambridge, 99 pp.

Stampfli, G.M. and Borel, G.D. (2002) A plate tectonic model for the Paleozoic and Mesozoic constrained by dynamic plate boundaries and restored synthetic ocean isochrones. Earth Planet. Sci. Lett., 196, 17-33.

Storrie-Lombardi, M.C. and Awramik, S.M. (2006) A sideways view of stromatolites: Complexity metrics for stromatolite laminae. In: Instruments, Methods and Missions for Astrobiology IX (Eds R.B. Hoover, G.V. Levin and A. Y Rozanov), Proc. SPIE, 6309, 1-12.

Suárez Vega, L.C. (1974) Estratigrafía del Jurásico en Asturias. Cuad. Geol. Iber., 3, 1-369.
Suárez-González, P., Quijada, I.E., Benito, M.I., Mas, R., Merinero, R. and Riding, R. (2014) Origin and significance of lamination in Lower Cretaceous stromatolites and proposal for a quantitative approach. Sed. Geol., 300, 1127.

Talbot, M.R. and Kelts, K. (1990) Paleolimnological signatures from carbon and oxygen isotopic ratios in carbonates from organic-rich lacustrine sediments. In: Lacustrine Exploration: Case Studies and Modern Analogues (Ed. B.J. Katz), AAPG Mem., 50, 99-112.

Thierry, J. (2000) Early Kimmeridgian. Map 10. In: Atlas Peri-Tethys. Palaeogeographical Maps. (Eds J. Dercourt, M. Gaetani, B. Vrielynck, E. Barrier, B. Biju-Duval, M.F. Brunet, J.P. Cadet, S. Crasquin and M. Sandulescu), pp. 85-97. Gauthier-Villars, Paris.

Uzqueda, H., Bulnes, M., Poblet, J., García-Ramos, J.C. and Piñuela, L. (2013) Buttressing and reverse reactivation of a normal fault in the Jurassic rocks of the Asturian Basin, NW Iberian Peninsula. Tectonophysics, 599, 117134.

Valenzuela, M., García-Ramos, J.C. and Suárez de Centi, C. (1986) The Jurassic sedimentation in Asturias (N Spain). Trabajos Geol. Univ. Oviedo, 16, 121-132.

Vázquez-Urbez, M., Arenas, C., Sancho, C., Osácar, C., Auqué, L. and Pardo, G. (2010) Factors controlling presentday tufa dynamics in the Monaterio de Piedra Natural Park (Iberian Range, Spain): depositional environmental settings, sedimentation rates and hydrochemistry. Int. J. Earth Sci. (Geol. Rundsch.), 99, 1027-1049.

Vázquez-Urbez, M., Arenas, C. and Pardo, G. (2012) A sedimentary facies model for stepped, fluvial tufa systems in the Iberian Range (Spain): the Quaternary Piedra and Mesa valleys. Sedimentology, 59, 502-526.

Vázquez-Urbez, M., Arenas, C., Pardo, G. and PérezRivarés, J. (2013) The effect of drainage reorganization and climate on the sedimentologic evolution of intermontane lake systems: the final fill stage of the Tertiary Ebro Basin (Spain). J. Sed. Res., 83, 562-590.

Woo, K.S., Khim, B.K., Yoo, H.S. and Lee, K.C. (2004) Cretaceous lacustrine stromatolites in the Gyeongsang Basin (Korea): records of cyclic change in paleohydrological condition. Geosci. J., 8, 179-184.

Zamarreño, I., Anadón, P. and Utrilla, R. (1997) Sedimentology and isotopic composition of Upper Palaeocene to Eocene non-marine stromatolites, eastern Ebro Basin, NE Spain. Sedimentology, 44, 159-176.

Manuscript received 16 April 2014; revision accepted 1 December 2014 


\section{APPENDIX 1. Mineralogical composition from X-Ray Diffraction Analyses (semi-quantitative weight percentage) of selected Vega Formation samples.}

\begin{tabular}{llll}
\hline & Calcite & Quartz & Phyllosilicates \\
\hline JLF-1 & $99 \cdot 00$ & $1 \cdot 00$ & $0 \cdot 00$ \\
JLF-2 & $95 \cdot 70$ & $4 \cdot 30$ & $0 \cdot 00$ \\
JLF-3 & $98 \cdot 52$ & $1 \cdot 48$ & $0 \cdot 00$ \\
JGV-1A & $39 \cdot 50$ & $46 \cdot 02$ & $14 \cdot 48$ \\
JGV-1B & $32 \cdot 94$ & $56 \cdot 09$ & $10 \cdot 97$ \\
JGV-4 & $89 \cdot 72$ & $10 \cdot 28$ & $0 \cdot 00$ \\
JGV-7 & $89 \cdot 40$ & $10 \cdot 60$ & $0 \cdot 00$ \\
JGV-8 & $62 \cdot 88$ & $24 \cdot 38$ & $12 \cdot 74$ \\
FG-1 & $96 \cdot 48$ & $1 \cdot 42$ & $2 \cdot 10$ \\
FG-2 & $96 \cdot 79$ & $1 \cdot 28$ & $1 \cdot 93$ \\
FG-3 & $96 \cdot 66$ & $1 \cdot 32$ & $2 \cdot 02$ \\
JAV-2 & $68 \cdot 41$ & $30 \cdot 09$ & $1 \cdot 50$ \\
JAV-3 & $62 \cdot 58$ & $25 \cdot 30$ & $12 \cdot 12$ \\
JLV-1 & $88 \cdot 80$ & $11 \cdot 20$ & $0 \cdot 00$ \\
JLV-2 & $71 \cdot 00$ & $29 \cdot 00$ & $0 \cdot 00$ \\
JVV-1 & $86 \cdot 26$ & $10 \cdot 63$ & $3 \cdot 11$ \\
\hline
\end{tabular}

JLF: La Fumarea; JGV: La Griega; JFG: Fuente del Gato; JAV: Abeu; JLV: Lastres; JVV: Vega (See Fig. 1B for location).

\section{APPENDIX 2. Stable-isotope values $\left(\delta^{13} \mathrm{C}\right.$ and $\left.\delta^{18} \mathrm{O}\right)$ of the different studied carbonate facies.}

\begin{tabular}{llllll}
\hline Samples & Sedimentary facies & & $\begin{array}{l}\text { Sampled components } \\
\text { for stable-isotope analysis }\end{array}$ & $\begin{array}{l}\delta^{13} \mathrm{C} \\
\% \text { V-PDB }\end{array}$ & $\begin{array}{l}\delta^{18} \mathrm{O} \\
\% \text { V-PDB }\end{array}$ \\
\hline JLF-1 & $\begin{array}{l}\text { Entire and broken oncoid and } \\
\text { stromatolite rudstone }\end{array}$ & JLF-1 & Laminated oncoidal coating & $-7 \cdot 80$ & $-4 \cdot 45$ \\
JLF-2 & Oncoids and microbial & & & \\
& laminated intraclast rudstone & JLF-2-1 & Laminated oncoidal coating & $-7 \cdot 83$ & $-3 \cdot 97$ \\
& & JLF-2-2 & Laminated oncoidal coating & $-7 \cdot 83$ & $-4 \cdot 67$ \\
JLF-3 & Oncoid rudstone & JLF-2-3 & Matrix among oncoids & $-7 \cdot 80$ & $-4 \cdot 75$ \\
& & JLF-3-1 & Dark porous interval in an oncoid & $-7 \cdot 61$ & $-5 \cdot 09$ \\
JGV-1A & Oncoid rudstone & JLF-3-2 & Light dense interval in an oncoid & $-7 \cdot 86$ & $-5 \cdot 48$ \\
& with extraclasts & JGV-1A-1 & Dark dense (thick) interval & $-5 \cdot 90$ & $-5 \cdot 03$ \\
& & JGV-1A-2 & Light porous (thick) interval & $-6 \cdot 09$ & $-4 \cdot 56$ \\
JGV-1B & Stromatolite & JGV-1A-3 & Dark dense (thick) interval & $-5 \cdot 79$ & $-4 \cdot 48$ \\
JGV-4 & Oncoid rudstone & JGV-1A-4 & Light porous interval & $-6 \cdot 33$ & $-5 \cdot 08$ \\
& & JGV-1B & Laminated interval & $-6 \cdot 25$ & $-4 \cdot 24$ \\
& & JGV-4-1 & Light porous interval in an oncoid & $-6 \cdot 74$ & $-4 \cdot 53$ \\
& & JGV-4-2 & Dark dense interval in an oncoid & $-6 \cdot 00$ & $-4 \cdot 73$ \\
JGV-8 & Oncoid-intraclast & JGV-4-3 & Light interval in an oncoid & $-6 \cdot 39$ & $-4 \cdot 97$ \\
& rudstone with extraclasts & JGV-4-4 & Dark interval in an oncoid & $-5 \cdot 91$ & $-4 \cdot 75$ \\
& & JGV-8-1 & Dark interval in an oncoid & $-6 \cdot 36$ & $-4 \cdot 50$ \\
& & JGV-8-3 & Light interval in an oncoid & $-6 \cdot 21$ & $-3 \cdot 95$ \\
& & Dark interval in an oncoid & $-5 \cdot 93$ & $-4 \cdot 30$ \\
& & & Light interval in an oncoid & $-6 \cdot 82$ & $-4 \cdot 61$ \\
\hline
\end{tabular}


Appendix 2. (continued)

\begin{tabular}{|c|c|c|c|c|c|}
\hline Samples & Sedimentary facies & & $\begin{array}{l}\text { Sampled components } \\
\text { for stable-isotope analysis }\end{array}$ & $\begin{array}{l}\delta^{13} \mathrm{C} \\
\% \text { V-PDB }\end{array}$ & $\begin{array}{l}\delta^{18} \mathrm{O} \\
\% \text { o-PDB }\end{array}$ \\
\hline FG-1A & Oncoid rudstone & $\begin{array}{l}\text { FG-1A-1 } \\
\text { FG-1A-2 } \\
\text { FG-1A-3 } \\
\text { FG-1A-4 } \\
\text { FG-1A-5 }\end{array}$ & $\begin{array}{l}\text { Dark interval (thick) in an oncoid } \\
\text { Light interval (thin) in an oncoid } \\
\text { Dark interval (thin) in an oncoid } \\
\text { Dark (+Light) interval (mixture) } \\
\text { Dark interval (thin) in an oncoid }\end{array}$ & $\begin{array}{l}-6 \cdot 19 \\
-6 \cdot 03 \\
-6 \cdot 12 \\
-6 \cdot 11 \\
-6 \cdot 28\end{array}$ & $\begin{array}{l}-4 \cdot 72 \\
-4 \cdot 76 \\
-4 \cdot 23 \\
-4 \cdot 95 \\
-4 \cdot 62\end{array}$ \\
\hline FG-1B & Oncoid rudstone & $\begin{array}{l}\text { FG-1B-1 } \\
\text { FG-1B-2 } \\
\text { FG-1B-3 } \\
\text { FG-1B-4 }\end{array}$ & $\begin{array}{l}\text { Dark interval in an oncoid } \\
\text { Light interval in an oncoid } \\
\text { Dark interval in an oncoid } \\
\text { Light interval in an oncoid }\end{array}$ & $\begin{array}{l}-6 \cdot 04 \\
-6 \cdot 25 \\
-6 \cdot 15 \\
-6 \cdot 26\end{array}$ & $\begin{array}{l}-4 \cdot 76 \\
-5 \cdot 17 \\
-4 \cdot 29 \\
-4 \cdot 78\end{array}$ \\
\hline FG-1C & Oncoid rudstone & $\begin{array}{l}\text { FG-1C-1 } \\
\text { FG-1C-2 } \\
\text { FG-1C-3 } \\
\text { FG-1C-4 } \\
\text { FG-1C-5 } \\
\text { FG-1C-6 }\end{array}$ & $\begin{array}{l}\text { Dark interval in an oncoid } \\
\text { Light interval in an oncoid } \\
\text { Dark interval in an oncoid } \\
\text { Light interval in an oncoid } \\
\text { Dark interval in an oncoid } \\
\text { Dark interval in an oncoid }\end{array}$ & $\begin{array}{l}-5 \cdot 93 \\
-5 \cdot 98 \\
-5 \cdot 86 \\
-6 \cdot 24 \\
-5 \cdot 95 \\
-6 \cdot 20\end{array}$ & $\begin{array}{l}-4 \cdot 72 \\
-4 \cdot 66 \\
-4 \cdot 75 \\
-4 \cdot 88 \\
-4 \cdot 92 \\
-4 \cdot 48\end{array}$ \\
\hline FG-3A & Oncoid rudstone & $\begin{array}{l}\text { FG-3A-1 } \\
\text { FG-3A-2 } \\
\text { FG-3A-3 } \\
\text { FG-3A-4 }\end{array}$ & $\begin{array}{l}\text { Light interval in an oncoid } \\
\text { Dark interval in an oncoid } \\
\text { Light interval in an oncoid } \\
\text { Dark interval in an oncoid }\end{array}$ & $\begin{array}{l}-6 \cdot 28 \\
-6 \cdot 20 \\
-6 \cdot 15 \\
-6 \cdot 11\end{array}$ & $\begin{array}{l}-4 \cdot 97 \\
-4 \cdot 72 \\
-5 \cdot 07 \\
-4 \cdot 76\end{array}$ \\
\hline JAV-3 & $\begin{array}{l}\text { Oncoid rudstone with } \\
\text { extraclasts }\end{array}$ & $\begin{array}{l}\text { JAV }-3-1 \\
\text { JAV-3-2 } \\
\text { JAV-3-3 }\end{array}$ & $\begin{array}{l}\text { Dark interval in an oncoid } \\
\text { Light interval in an oncoid } \\
\text { Dark interval in an oncoid }\end{array}$ & $\begin{array}{l}-5 \cdot 36 \\
-6 \cdot 08 \\
-5 \cdot 43\end{array}$ & $\begin{array}{l}-5 \cdot 46 \\
-5 \cdot 95 \\
-5 \cdot 60\end{array}$ \\
\hline JLV-1 & Oncoid-intraclast rudstone & $\begin{array}{l}\text { JLV-1-1 } \\
\text { JLV-1-2 } \\
\text { JLV-1-3 }\end{array}$ & $\begin{array}{l}\text { Dark + Light laminae (mixture) } \\
\text { Dark + Light laminae (mixture) } \\
\text { Matrix among oncoids }\end{array}$ & $\begin{array}{l}-5 \cdot 67 \\
-5 \cdot 85 \\
-6 \cdot 91\end{array}$ & $\begin{array}{l}-5 \cdot 37 \\
-5 \cdot 55 \\
-6 \cdot 10\end{array}$ \\
\hline JLV-2 & $\begin{array}{l}\text { Oncoid-intraclast } \\
\text { rudstone with extraclasts }\end{array}$ & $\begin{array}{l}\text { JLV-2-1 } \\
\text { JLV-2-2 }\end{array}$ & $\begin{array}{l}\text { Matrix among oncoids } \\
\text { Laminated oncoidal coating }\end{array}$ & $\begin{array}{l}-6 \cdot 18 \\
-6 \cdot 27\end{array}$ & $\begin{array}{l}-4 \cdot 71 \\
-4 \cdot 80\end{array}$ \\
\hline
\end{tabular}

JLF: La Fumarea; JGV: La Griega; JFG: Fuente del Gato; JAV: Abeu; JLV: Lastres; JVV: Vega (See Fig. 1B for location). 